\title{
Interest rate pass-through in the common monetary area of the SACU countries
}

Citation for published version (APA):

Sander, H., \& Kleimeier, S. (2006). Interest rate pass-through in the common monetary area of the SACU countries. Maastricht University School of Business and Economics. METEOR Research Memorandum No. 023 https://doi.org/10.26481/umamet.2006023

Document status and date:

Published: 01/01/2006

DOI:

10.26481/umamet.2006023

Document Version:

Publisher's PDF, also known as Version of record

\section{Please check the document version of this publication:}

- A submitted manuscript is the version of the article upon submission and before peer-review. There can be important differences between the submitted version and the official published version of record.

People interested in the research are advised to contact the author for the final version of the publication, or visit the DOI to the publisher's website.

- The final author version and the galley proof are versions of the publication after peer review.

- The final published version features the final layout of the paper including the volume, issue and page numbers.

Link to publication

\footnotetext{
General rights rights.

- You may freely distribute the URL identifying the publication in the public portal. please follow below link for the End User Agreement:

www.umlib.nl/taverne-license

Take down policy

If you believe that this document breaches copyright please contact us at:

repository@maastrichtuniversity.nl

providing details and we will investigate your claim.
}

Copyright and moral rights for the publications made accessible in the public portal are retained by the authors and/or other copyright owners and it is a condition of accessing publications that users recognise and abide by the legal requirements associated with these

- Users may download and print one copy of any publication from the public portal for the purpose of private study or research.

- You may not further distribute the material or use it for any profit-making activity or commercial gain

If the publication is distributed under the terms of Article $25 \mathrm{fa}$ of the Dutch Copyright Act, indicated by the "Taverne" license above, 
Harald Sander, Stefanie Kleimeier

Interest Rate Pass-Through In the Common Monetary Area of the SACU Countries

$\mathrm{RM} / 06 / 023$

JEL code: E43, E52, E58, F36

\section{METE@R}

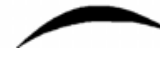

Maastricht research school of Economics

of TEchnology and ORganizations

Universiteit Maastricht

Faculty of Economics and Business Administration P.O. Box 616

NL - 6200 MD Maastricht

phone : ++31433883830

fax $\quad$ : ++31433884873 

This Version: March 10, 2006

\title{
InTERest Rate Pass-Through In The Common Monetary AREA OF THE SACU COUNTRIES $^{1}$
}

\author{
by
}

Harald Sander $^{\mathrm{a}, \mathrm{c}^{*}}$ and Stefanie Kleimeier ${ }^{\mathrm{b}, \mathrm{c}}$

\footnotetext{
a. Faculty of Economics and Business Administration, University of Applied Sciences Cologne, Claudiusstr.1, 50678 Köln, Germany.

b. Limburg Institute of Financial Economics, Maastricht University, Tongersestraat 53, 6211 LM Maastricht, The Netherlands.

${ }^{c}$ METEOR, Maastricht University, Tongersestraat 53, 6211 LM Maastricht, The Netherlands.
}

\begin{abstract}
This study investigates the interest rate pass-through in the four Common Monetary Area (CMA) countries of the South African Customs Union (SACU) during the period from 1991 to 2005. We employ a unifying empirical pass-through model that allows for thresholds, asymmetric adjustment, and structural changes over time. Our results show that the bank lending markets of the CMA exhibit quite some degree of homogenization as the pass-through is often fast and complete. Deposit markets are somewhat more heterogeneous by showing differing degrees of interest rate stickiness and asymmetric adjustment in some countries. Policy makers should therefore be concerned about imperfect competition which may be at the heart of the remaining cross-country differences in monetary transmission in the CMA.
\end{abstract}

JEL Classification Numbers: E43; E52; E58; F36.

Keywords: Interest Rate Pass-Through, Monetary Policy, Common Monetary Area, SACU, African Banking, Competition in Banking, Asymmetric Adjustment, Structural Breaks.

* Corresponding author. Tel: +49-221-82753419; fax: +49-221-82753131; E-mail address: gh.sander@t-online.de (Harald Sander)

\footnotetext{
${ }^{1}$ The authors would like to thank the participants of the research seminar presentation at the Business School at the University of Namibia, $23^{\text {rd }}$ September 2005, for their helpful comments on suggestions. All remaining errors are ours. The final version of this study will be published in Volume 74:2 of the South African Journal of Economics in June 2006 and made available at www.blackwell-synergy.com.
} 


\section{$\underline{1 . \text { Introduction }}$}

Among the five members of the Southern African Custom Union (SACU), South Africa, Lesotho, Namibia, and Swaziland form a Common Monetary Area (CMA) and only the fifth SACU member, Botswana, remains outside the CMA. In the presence of free capital movements, members of a currency union forego individual monetary autonomy. In contrast to the recently formed European Monetary Union however, the four CMA countries do not have a supranational central bank conducting the monetary policy. Rather, the four countries conduct a quasi currency board arrangement with the South African Rand as the anchor currency. This leads to a number of important research questions with respect to the workings of monetary policy in these countries. First, how does the monetary transmission process work in these four countries? Second, how does national monetary policy and its effects depend on the anchor country's monetary policy? Third, how similar are the responses to monetary policy impulses across the member countries? One avenue to investigate these issues is the use of vector auto regression (VAR) models of monetary policy. A different strategy is to separate the monetary transmission process analytically into a financial and a real part. Especially for countries like the CMA members where bank lending is the most important form of financial intermediation and which have been undergoing important and deep financial reforms, it makes sense to concentrate more deeply on the financial part of the transmission process with a particular emphasis on the role of structural change. Our paper will address the three issues mentioned above with respect to changing financial market structures in the CMA.

A widely used methodology to investigate the financial part of the monetary transmission process is interest rate pass-through (PT) estimation which can reveal how fast and how complete changes in monetary policy rates are passed onto bank lending and deposit rates. However, the speed and the size (completeness) of the PT depend on the banking market structure and potential information asymmetries. Thus, PT studies can also reveal 
information about competition in banking markets. In an international context, PT studies can furthermore reveal asymmetries across countries under a single monetary policy (Sander and Kleimeier, 2004). This methodology has extensively been applied to the euro zone and seen a number of recent refinements more recently. PT studies are based on a variant of the pioneering work by Cottarelli and Kourelis (1994). Important contributions include BIS (1994), Cottarelli, Ferri and Generale (1995), Borio and Fritz (1995), Mojon (2000), de Bondt et al. (2002), Sander and Kleimeier (2002), Toolsema, Sturm and de Haan (2002), Heinemann and Schüler (2003), de Bondt (2004), and De Graeve et al. (2004). Typically these studies find a substantial degree of short-run bank interest rate stickiness, partly even a long-run lack of a full PT which may point to the existence of credit rationing phenomena (Stiglitz and Weiss, 1981) and considerable differences in the PT across the countries of the euro zone. Furthermore, asymmetric adjustment of bank interest rates depending on the type of interest rate shock is regularly documented. Despite these commonalties, the existing studies often use differing approaches and consequently lead to diverging results. Sander and Kleimeier (2004) therefore introduce a unifying methodological framework for analyzing the PT process in the euro zone. Looking to the CMA countries the lack of PT studies is striking. A notable exemption is Aziakpono (2005) who focuses however on the use of PT results as a measure of financial integration. By investigating how central bank and bank interest rates depend on each other across CMA countries, he interprets his empirical findings as a support the South African Dominance (SAD) hypothesis, i.e. South African interest rates are influencing the other countries' policy and bank interest rates. However, he attributes this convergence not so much a result of market convergence, i.e. arbitrage in financial markets, but to policy convergence, i.e. the central banks adhere to the quasi currency board arrangements and adjust the policy rates to the South African rates.

Our study directly investigates the PT in all four CMA countries. Taking into account Aziakpono's SAD hypothesis we will investigate both, how national bank rates react to 
national monetary policy rate changes and how they react to South African monetary policy rate changes. In doing so, we use discount rates as well as T-bill rates as proxies for the monetary policy stance. Given the changing financial structures over time we first conduct structural break tests which search for an unknown, endogenously determined break point. After identifying break-free (sub-)periods we estimate the PT by means of an automatically selected PT model out of a large variety of symmetric, asymmetric, and threshold models. The results shed light on three issues: (1) the workings and changes of the financial part of the monetary transmission process in all four CMA countries, (2) the effectiveness and competition in the national banking markets, and (3) the role and importance of a potentially differential impact of the South African monetary policy on bank interest rates in the other CMA countries. The plan of the paper is as follows. Section 2 provides the methodology and data description. In section 3 we discuss the results of our analyses and section 4 concludes.

\section{Data and Methodology}

Our study focuses on four CMA countries South Africa, Lesotho, Namibia, and Swaziland. For these countries we collect monthly data from January 1991 to May 2005 for two bank interest rates and two proxies of the monetary policy rate: Prime lending rates, deposit rates, Treasury bill rates, and discount rates. The data are obtained from Datastream who in turn collects these series from the lines $60 \mathrm{p}, 601,60 \mathrm{c}$, and 60 of the IFS, respectively. The Namibian Treasury bill and discount rate series are incomplete and have been completed with data directly obtained from the Namibian central bank. The development of these rates over time is presented in Figures 1.

(Insert Figure 1 about here) 
Following Sander and Kleimeier $(2004)^{1}$, we model the PT based on a unifying empirical approach that also allows for long-run cointegration relationships as well as asymmetric and threshold adjustment. Our empirical PT model can take one of the three basic forms:

$$
\begin{aligned}
& \mathrm{BR}_{\mathrm{t}}=\beta_{0}+\sum_{\mathrm{i}=1}^{\mathrm{k}^{*}} \beta_{\mathrm{BR}, \mathrm{i}} \mathrm{BR}_{\mathrm{t}-\mathrm{i}}+\beta_{1} \mathrm{M}_{\mathrm{t}}+\sum_{\mathrm{i}=1}^{\mathrm{n} *} \beta_{\mathrm{M}, \mathrm{i}} \mathrm{M}_{\mathrm{t}-\mathrm{i}}+\varepsilon_{\mathrm{t}} \\
& \Delta \mathrm{BR}_{\mathrm{t}}=\sum_{\mathrm{i}=1}^{\mathrm{k}^{*}} \beta_{\mathrm{BR}, \mathrm{i}} \Delta \mathrm{BR}_{\mathrm{t}-\mathrm{i}}+\beta_{1} \Delta \mathrm{M}_{\mathrm{t}}+\sum_{\mathrm{i}=1}^{\mathrm{n}^{*}} \beta_{\mathrm{M}, \mathrm{i}} \Delta \mathrm{M}_{\mathrm{t}-\mathrm{i}}+\varepsilon_{\mathrm{t}} \\
& \Delta \mathrm{BR}_{\mathrm{t}}=\sum_{\mathrm{i}=1}^{\mathrm{k}^{*}} \beta_{\mathrm{BR}, \mathrm{i}} \Delta \mathrm{BR}_{\mathrm{t}-\mathrm{i}}+\beta_{1} \Delta \mathrm{M}_{\mathrm{t}}+\sum_{\mathrm{i}=1}^{\mathrm{n}^{*}} \beta_{\mathrm{M}, \mathrm{i}} \Delta \mathrm{M}_{\mathrm{t}-\mathrm{i}}+\beta_{\mathrm{ECT}} \mathrm{ECT}_{\mathrm{t}-1}+\varepsilon_{\mathrm{t}}
\end{aligned}
$$

where $\mathrm{BR}_{\mathrm{t}}$ and $\mathrm{M}_{\mathrm{t}}$ are national bank and monetary policy proxy rates, respectively, and $\mathrm{k}^{*}$ and $\mathrm{n}^{*}$ indicate the optimal lag lengths. ${ }^{2}$ Equation (1) describes the PT model as a standard model in levels (STD_LL) and is chosen for interest rates that exhibit an $\mathrm{I}(0)$ property. However, since interest rates are often found to be I(1), the empirical PT model is best estimated using first differences as stated in equation (2). This standard specification (STD) avoids spurious regression problems but leads to a loss of information about long-run relationships. If BR and $M$ are cointegrated, this information can fortunately be recovered. Equation (2) then needs to be augmented by a lagged error correction term $\left(\mathrm{ECT}_{\mathrm{t}-1}\right)$ as shown in equation (3). By estimating the long-run cointegration relationship (4) the ECT can be obtained as shown in equation $(5)^{3}$ :

$$
\begin{aligned}
& \mathrm{BR}_{\mathrm{t}}=\theta_{0}+\theta \mathrm{M}_{\mathrm{t}}+\mathrm{u}_{\mathrm{t}} \\
& \mathrm{ECT}_{\mathrm{t}-1}=\mathrm{u}_{\mathrm{t}-1}
\end{aligned}
$$

Given that financial markets in CMA countries have been undergoing structural changes we will first test for structural breaks in the relationship between the monetary policy

\footnotetext{
${ }^{1}$ This methodology section is largely based on Sander and Kleimeier (2004).

${ }^{2}$ Whenever an optimal lag length has to be determined, the minimum AIC criterion is used allowing for a maximum of four lags.
} 
rate proxy and the national bank rate. We determine the presence and timing of the break endogenously by estimating a supremum $\mathrm{F}$ (supF) test for equation (4). ${ }^{4}$ This test can be interpreted as a rolling test since standard Chow tests are conducted for a series of different break points, which move through the mid- $80 \%$ of the sample period. ${ }^{5}$ On the basis of these tests we construct - when appropriate - pre- and post-break periods for every national bank interest rate. This allows us to obtain additional information on the timing of structural changes and to estimate PT models for break-free sample periods.

In estimating the PT we allow for different types of adjustment pattern. If the ECT is defined as in equation (5), a symmetric adjustment model (SYM) is estimated, where the adjustment mechanism is independent of the state of the dis-equilibrium. However, the PT process is often characterized by threshold and asymmetric adjustment mechanisms. Next to the symmetric error-correction process we therefore consider several asymmetric specifications for the adjustment of interest rates. These state-dependent models all belong to the group of threshold autoregressive (TAR) models and differ with respect to the definition of the ECT.

A first state-dependent adjustment mechanism allows for differing adjustment speed above or below a given threshold. In the simplest case of the $\operatorname{TAR}^{0}$ model ${ }^{6}$ this threshold is set to zero, typically implying different adjustment speed to rising versus falling monetary policy rates. Thus, the ECT becomes:

$$
\mathrm{ECT}_{\mathrm{t}-1}=\mathrm{I}_{\mathrm{t}} \mathrm{u}_{\mathrm{t}-1}+\left(1-\mathrm{I}_{\mathrm{t}}\right) \mathrm{u}_{\mathrm{t}-1} \quad \text { with } \mathrm{I}_{\mathrm{t}}=1 \text { if } \mathrm{u}_{\mathrm{t}-1} \geq \mathrm{a}_{0}{ }^{*} \text { and } 0 \text { otherwise }
$$

where $\mathrm{I}_{\mathrm{t}}$ represents a Heaviside indicator for different states of $\mathrm{u}_{\mathrm{t}-1}$ and $\mathrm{a}_{0} *=0$. The second asymmetric model (TAR*) is a modification of the $\mathrm{TAR}^{0}$ such that the threshold $\mathrm{a}_{0} *$ is now

\footnotetext{
${ }^{3}$ Cointegration testing is based on the Durbin-Watson (DW), Dickey-Fuller (DF) and augmented Dickey-Fuller (ADF) tests.

${ }^{4}$ Strictly speaking equation (4) can only be interpreted as a long-run cointegration relationship when all interest rates are $\mathrm{I}(1)$. This condition is, however, fulfilled for all interest rates under investigation here.

${ }^{5}$ For details on this test see Andrews (1993), Diebold and Chen (1996), and Hansen (1992). SupF equals the largest Chow F-statistic and is compared to critical values as reported by Hansen (1992).

${ }^{6}$ See Tong (1983).
} 
allowed to deviate from zero. The rationale is that bank rates may adjust differently to a disequilibrium once a certain minimum deviation in one direction is exceeded. The third variation is a Band-TAR model (B-TAR*), which can reflect both interest rate smoothing as well as interest rate stickiness. For this model, the ECT is defined as

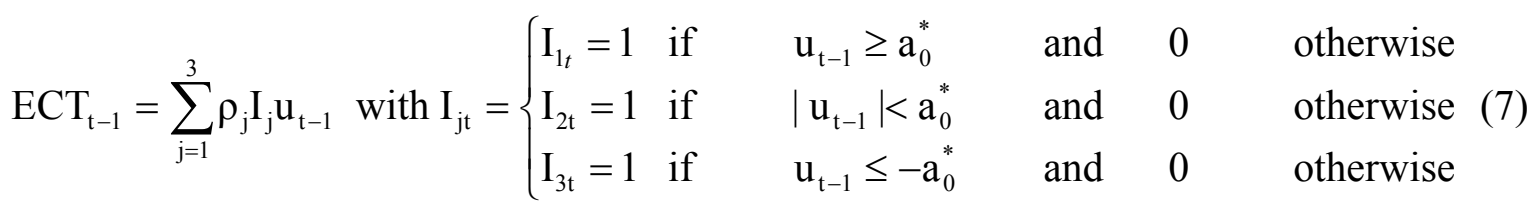

Finally, our fourth and fifth asymmetric models represent momentum threshold autoregressive models $\left(\mathrm{M}-\mathrm{TAR}^{0}, \mathrm{M}-\mathrm{TAR}^{*}\right)$ where the adjustment depends on the speed of deviation from equilibrium. Therefore, M-TAR adjustment can reflect behavior of banks, which attempt to smooth out large market rate changes. In these models, the ECT depends on the change in the error correction term $\Delta \mathrm{u}_{\mathrm{t}-1}$ such that

$$
\mathrm{ECT}_{\mathrm{t}-1}=\mathrm{I}_{\mathrm{t}} \rho_{1} \Delta \mathrm{u}_{\mathrm{t}-1}+\left(1-\mathrm{I}_{\mathrm{t}}\right) \rho_{2} \Delta \mathrm{u}_{\mathrm{t}-1} \text { with } \mathrm{I}_{\mathrm{t}}=1 \text { if } \Delta \mathrm{u}_{\mathrm{t}-1} \geq \mathrm{a}_{0}{ }^{*} \text { and } 0 \text { otherwise (8) }
$$

with $\mathrm{a}_{0}=0$ for the $\operatorname{MTAR}^{0}$ model and $\mathrm{a}_{0}=\mathrm{a}_{0} *$ for the MTAR* model. $^{7}$

In order to find the empirical PT model that optimally fits the data we follow an (almost) automatic model selection procedure: We first investigate the unit root characteristics of each interest rate. By applying unit root tests which are well specified even in the presence of a structural break, we can simply focus on the full sample period here. Next, we test for structural breaks in the long-run relationship in order to define break-free (sub-)periods. For the full sample period as well as for all sub-periods we conduct the following model selection process: In case of $\mathrm{I}(0)$ for both BR and $\mathrm{M}$ we choose the STD_LL model as the optimal PT model. Otherwise, we proceed with cointegration testing. We first estimate all TAR-type models and select that TAR-type model which best fits the data based on the AIC criterion. For this model, we conduct cointegration and asymmetry tests. If asymmetric cointegration is

\footnotetext{
${ }^{7}$ For cointegration testing in TAR-type models see Enders and Siklos (2000). Regarding the determination of the optimal threshold $\mathrm{a}_{0} *$ see Chan (1993). With respect to the calculations of multipliers see Sander and Kleimeier (2004).
} 
confirmed, the PT model is set as the best TAR-type model. If asymmetric cointegration is not confirmed, we continue with symmetric cointegration testing. If symmetric cointegration is found, the PT model is set as SYM. If symmetric cointegration is rejected, we select the standard model (STD). Based on the selected PT models, we obtain multipliers of different time horizons (impact, 1, 3, 6, 12 months, and long run) and different interest rate shocks ($1 \%,-0.5 \%,+0.5 \%,+1 \%)$.

\section{$\underline{\text { 3. Evidence on Pass-Through Changes in CMA Countries }}$}

\subsection{The Changing Long-Run Relation between Monetary Policy and Bank Interest Rates}

We start our investigation by testing if the interest rates in our sample are integrated of order 1 . Our unit root tests confirm the requested property. ${ }^{8}$ Thus, the long-run relationship between the driving monetary policy rates such as the national and South African (SA) discount and T-bill rates and the national bank rates based on equation (4) can be visualized as a possible cointegrating relationship. Next we test for endogenous structural breaks in this long-run relationship. The critical values depend on the model and the number of observation, but as a rule of thumb one can say that a value above 15 for the supF-test indicates a structural break. Figure 2 illustrates the results of our supF-tests and clearly indicates the pattern of structural change in the CMA banking markets. ${ }^{9}$

(Insert Figure 2 about here)

Starting with South Africa, we find a stable relationship between discount rates and lending rates, but clear evidence for a break in the relation to the deposit rate in May 1997. When the T-bill rate is considered as the driving rate (see Panel $\mathrm{C}$ of Figure 1) the estimated

\footnotetext{
${ }^{8}$ For details see Table A1 in the Appendix.
} 
break point for deposit rates is slightly later in September 1998. Moreover, the long-run relation between T-bill and lending rates also shows a break in May 1997. All rates are cointegrated in all sub-periods. Deposit rates show a more than full PT with respect to discount rates before the break and a slightly less than full PT after the break. Also with respect to T-bill rates the size of the PT has slightly been reduced but is now remarkably close to one. This could indicate that T-bills are almost perfect substitutes for deposits - at least in the long run. Thus this result can provide a benchmark for the other CMA countries. With respect to lending we also find full $\mathrm{PT}$ in response to the discount rate. However, with respect to the T-bill rate there was no full PT before the break. This situation has changed to the effect that we now find more than full PT. In sum, it appears that today we find a full long-run PT in South Africa for both loans and deposits with the national T-bill rate playing an increasingly important role as the driving interest rate.

Moving to Lesotho we find strong evidence for structural breaks in the deposit market in the late 1990, regardless which driving rate is considered. With respect to lending, structural changes are increasingly becoming visible in the recent years only. We also use South African rates as driving rates and obtain an interesting result: Deposit rates have similar break points regardless whether national or South African driving rates are being considered. The break points for lending rates reaction to South African driving rates are also found to be around the late 1990s and are therefore preceding the break points with respect to national policy rates - which occur in 2003 only - by some five years. Lending rates in Lesotho show in the post-break period a full PT with respect to the national discount rate and the SA T-bill rate. This could suggest that SA T-bill impact on national lending rate via their impact on national discount rates. The size of the PT for deposit rates has generally become somewhat smaller over time. This is especially true with respect to national discount rate where the long-

\footnotetext{
${ }^{9}$ The exactly determined structural breaks can be obtained from Table A2 in the Appendix. The sample period is then split into a pre- and post-break period and cointegration testing proceeds with results reported in Table A3 in the Appendix.
} 
term PT is down to 0.26. Here it appears that the impact of the South African discount rate with a PT size of 0.54 is somewhat higher. However, like in South Africa the T-bill rate shows a higher PT with coefficients of 0.66 (national T-bill) and 0.61 (SA T-Bill), respectively. Unlike in South Africa there is no full PT for deposit rates, indicating a relatively less competitive deposit market in Lesotho.

Swaziland's deposit markets show structural breaks as early as September 1994 (national discount rate), September 1992 (SA discount rate) and October 1992 (SA T-bill rate). Before these early break points, the PT was rather low, which eventually could have been caused by the small sample size. After these break points, the size of the PT has become remarkably high (0.86 national discount rate, $0.75 \mathrm{SA}$ discount rate, $0.84 \mathrm{SA}$ T-bill rate) though it is still falling behind the PT-efficiency of South Africa. With respect to the national T-bill rate we find a rather late break in April 2003. This break indicates that the efficiency of the PT in Swaziland has improved from 0.78 and 0.88 , thus confirming the increasing importance of this rate for the pricing of deposits. With respect to Swaziland's lending rates our results are influenced completely by the fact that the lending rates are fully tied to the national discount rate. Thus we obtain a break point in August 2003 when the spread was allowed to increase from $3 \%$ to $3.5 \%$. Consequently, the results for the other driving rates are not influenced by credit market conditions but by the relationship between them and the national discount rate. Given the less-than one-to-one relationship amongst them the PT size is typically less than one, except for the period from September 2001 when the Swaziland's discount rate has been tied one-to-one to the South African discount rate.

Namibia's deposit markets are most distinct from those of the other CMA countries. With respect to the national discount rate the estimated break point is in October 1995. After this break the policy rate is not cointegrated anymore with the deposit rates and the PT after 
the break is only $0.38 .^{10}$ All other driving rates show break points in late 1999 to early 2000 . The South African discount rate is now of no relevance to the deposit rate-PT in Namibia. ${ }^{11}$ In fact, it is the T-bill rate that influences deposit rates in Namibia. With long-run PT coefficients of 0.58 (national T-bill) and 0.49 (SA T-bill), the PT size is however the lowest among CMA deposit markets. Moreover, our estimates show that these numbers have somewhat decreased in the post-break period. Namibian lending markets show early breakpoints around 1994 for all driving rates except the national discount rate where no break was found. Concentrating thus on the current period, we find an almost full PT with respect to national and South-African T-bill rates, while there is a somewhat smaller "discount-rate addiction" as revealed by a long-run PT multiplier of 0.85 (national discount rate) and 0.89 (SA discount rate). However, looking again at Figure 1 shows that a second peak is building up in the early 2000 s indicating the potential presence of a new structural break between the Namibian lending rate and the T-bill rates which can be investigated further in future studies.

In sum, we find a quite strong PT in CMA banking markets not only for loans but also for deposits. Compared to results documented for the European Monetary Union (see e.g. Sander and Kleimeier, 2004) the PT in CMA countries is thus comparatively more efficient, for both loans and deposits. Country differences are found, but are not dramatic, especially with respect to loans. The largest difference are found in the long-run PT for deposits with South Africa showing a full PT while Namibia exhibits the lowest PT size. Generally it is found that the T-bill rates are playing an increasingly more important role compared to classical policy rates, such as the discount rate. Moreover, given the efficiency of the PT, the monetary policy of South Africa has a direct influence on the bank rates in all CMA countries. This impact is increasingly mediated through T-bill markets and - at times - monetary

\footnotetext{
${ }^{10}$ Note that in this case we cannot use the slope coefficient of the cointegration regression reported in Table A3 in the appendix as an estimator for the long-run multiplier. Instead, the long-run multiplier is obtained from the STD-model estimate provided in Table A5 in the Appendix.

${ }^{11}$ Again we do not find cointegration. The long-run multiplier obtained from the STD model is only 0.08 .
} 
conditions in South Africa show an even stronger influence on national bank rates than national conditions as measured by national driving interest rates.

\subsection{Short-Run Dynamics and Asymmetries in Bank Rate Adjustments}

Next to the long-run, we also estimate optimal short-run and possibly asymmetric PT models for all rates, countries and sub-periods and thereby obtain measures for the speed of the PT. ${ }^{12}$ In very few cases, notably for Lesotho's relationship between lending rate and national discount rate and Swaziland's relationship between the deposit rate and the national T-bill rate, our methodology selects asymmetric models which yield implausible results due to the very short estimation period in the post-break period. In these cases we also supply results for the less data-demanding symmetric model. In Table 1 we have compiled an overview of the results by concentrating on current multipliers for the post-break period.

(Insert Table 1 about here)

Starting with deposits we can confirm the well-document phenomenon of short-run stickiness of deposit rates. However, South Africa and Swaziland have the least sticky deposit rates while the impact multiplier in Lesotho and even more so in Namibia are very small. However, typically three months after a monetary policy shock deposit rate are moving already closer to the long-run equilibrium. Regarding asymmetries we find that deposit rates adjust somewhat faster downward than upward - a typical sign of imperfect competition. For illustrative purposes we have also calculated unweighted averages of the obtained multipliers. They confirm that not only in the long but also in the short run T-bill rates play a quantitatively more important role in influencing deposit rates. And given the impact of South African T-bill rates on other CMA countries' financial markets it can be shown that this rate 
could even have a more important effect on national deposit market than national discount rates, but only when they are moving upward.

In lending markets also some stickiness is found as measured by the impact multipliers. Interestingly, on average South African T-bill rates seem to be of most important in the very short run. An explanation could be that policy maker in the other CMA countries react with their policy rates to movements in the South African T-bill market as suggested by Aziakpono (2005), and - if this is anticipated by market participants - lending rates may adjust immediately. This argument can be supported by the results for the interim multipliers which show a certain "discount rate addiction". This is partly due to loan rate indexing in Swaziland and some "overshooting" in Lesotho. But also in other countries the reaction to discount rate changes sets in rather soon, so that long-run multipliers are almost fully approached after three or six months. We also find only few asymmetries which are rather specific for one or two countries in their reaction to certain driving rates only. It is thus remarkable that the PT reacts to and depends on the South African rates not only in size but also in speed.

In sum, we find a quiet homogeneous PT process for lending rates and a less homogeneous one for deposit rates in the CMA countries. South African T-bill rates play an important role to influence national discount rates, national T-bill rates and finally bank interest rates. In this respect our study confirms the finding of Aziakpono (2005) who has attributed his empirical support for the South African Dominance hypothesis to policy convergence, i.e. that central banks adjust the policy rates to the South African rates. The PT is rather fast by international standards even for deposits which nevertheless indicate the presence of market imperfection by showing signs of short- and long-run stickiness as well as some asymmetric adjustment pattern, such as a faster downward adjustment of deposit rates.

\footnotetext{
${ }^{12}$ The detailed statistics for the model selection can be found in table A4 in the Appendix. The resulting multipliers can be found in Table A5 in the Appendix.
} 


\section{Conclusions}

The banking markets of the CMA exhibit quite some degree of integration with an important role of the South African T-bill rates in driving national policy, market and bank interest rates. With respect to lending markets the interest PT across all four countries is rather but not perfectly homogenous. We often find a full PT in the long-run with a relatively fast adjustment over some six month to the major driving interest rates. These adjustments take place with only few asymmetries. With respect to deposit markets the PT is more heterogeneous across countries with South Africa on the one hand exhibiting a full and fast PT and Namibia on the other hand exhibiting more deposit rate stickiness and adjustment asymmetries thus pointing to some degree of market imperfection. Policy makers therefore should not only be concerned with integration policies but also competition policies which may be at the heart of the remaining cross-country differences in monetary transmission in the CMA. 


\section{$\underline{\text { References }}$}

Andrews, D.W.K., 1993. Tests for parameter instability and structural change with an unknown change point. Econometrica 61 (4), 821-856.

Aziakpono, M., 2005. Financial integration amongst the SACU countries: Evidence from interest rate pass-through analysis. Paper presented at the $10^{\text {th }}$ Annual Conference on Econometric Modeling in Africa., July 6-8, Nairobi.

Bank for International Settlements, 1994. National differences in interest rate transmission. CB Document 393, Basle.

Bondt, G. de, 2004. Interest rate pass-through: Empirical results for the euro area. German Economic Review 6, 37-78.

Bondt, G. de, Mojon, B., Valla, N., 2002. Interest rate setting by universal banks and the monetary policy transmission mechanism in the euro area. Unpublished working paper, European Central Bank, Frankfurt.

Borio, C.E.V., Fritz, W., 1995. The response of short-term bank lending rates to policy rates: A cross-country perspective. In: Bank for International Settlements, Financial structure and the monetary transmission mechanism. CB Document 394, Basle, pp. 106-153.

Chan, K.S., 1993. Consistency and limiting distribution of the least squares estimator of a threshold autoregressive model. The Annals of Statistics 21, 520-533.

Cottarelli, C., Ferri, G., Generale, A., 1995. Bank lending rates and financial structure in Italy: a case study. IMF Working Paper 95/38, Washington, DC.

Cottarelli, C., Kourelis, A., 1994. Financial structure, bank lending rates, and the transmission mechanism of monetary policy. IMF Staff Papers 41 (4), Washington, DC.

De Graeve, F., De Jonghe, O., Vander Vennet, R., 2004. Competition, transmission and bank pricing policies: Evidence from Belgian loan and deposit markets. Ghent University's Department of Financial Economics Working Paper 2004/261. 
Diebold, F.S., Chen, C., 1996. Testing structural stability with endogenous breakpoint - a size comparison of analytic and bootstrap procedures. Journal of Econometrics 70 (1), 221241.

Enders, W., Siklos, P.I., 2000. Cointegration and threshold adjustment. Unpublished working paper, Iowa State University, Ames, IA.

Hansen, B.E., 1992. Tests for parameter instability in regressions with I(1) processes. Journal of Business \& Economic Statistics 10 (3), 321-341.

Heinemann, F., Schüler, M., 2003. Integration benefits on EU retail credit markets - Evidence from interest rate pass-through. In: Cecchini, P., The incomplete European market for financial services. Springer Verlag, Berlin, pp. 105-129.

Mojon, B., 2000. Financial structure and the interest channel of the ECB monetary policy. ECB Working Paper No. 40, Frankfurt.

Sander, H., Kleimeier, S., 2004. Convergence in euro-zone retail banking? What interest rate pass-though tells us about monetary policy transmission, competition and integration. Journal of International Money and Finance 23, 461-492.

Sander, H., Kleimeier, S., 2002. Asymmetric adjustment of commercial bank interest rates in the Euro area: An empirical investigation into interest rate pass-through. Kredit und Kapital 35 (2), 161-192.

Stiglitz, J., Weiss, A., 1981, Credit rationing in markets with imperfect information. American Economic Review 69, 339-345.

Tong, H., 1983. Threshold models in non-linear time series. Lecture Notes in Statistics 21, Springer Verlag, Berlin.

Toolsema, L.A., Sturm, J.-E., de Haan, J., 2002. Convergence of monetary transmission in EU: New evidence. CESifo Working Paper 465, Munich. 


\section{Appendix}

(Insert Tables A1 toA5 here) 
Table 1: Selected Current Multipliers Based on Optimal Pass-Through Model

\begin{tabular}{|c|c|c|c|c|c|c|c|c|c|c|}
\hline \multirow[b]{2}{*}{ country } & \multirow[b]{2}{*}{ driving rate } & \multicolumn{2}{|c|}{ sample period } & \multirow[b]{2}{*}{ model } & \multirow{2}{*}{$\begin{array}{r}\text { impact } \\
\text { multiplier }\end{array}$} & \multirow{2}{*}{$\begin{array}{r}3 \text { mth } \\
\text { upward }\end{array}$} & \multirow{2}{*}{$\begin{array}{r}3 \text { mth } \\
\text { downward }\end{array}$} & \multirow{2}{*}{$\begin{array}{c}6 \mathrm{mth} \\
\text { upward }\end{array}$} & \multirow{2}{*}{$\begin{array}{c}6 \mathrm{mth} \\
\text { downward }\end{array}$} & \multirow[b]{2}{*}{ long-run } \\
\hline & & start & $\overline{\text { end }}$ & & & & & & & \\
\hline \multicolumn{11}{|l|}{ Panel A: Deposit Rate } \\
\hline \multirow[t]{2}{*}{ South Africa } & national discount & 1997.06 & 2005.05 & MTAR* & 0.50 & 1.11 & 1.22 & 0.84 & 0.85 & 0.91 \\
\hline & national T-bill & 1998.09 & 2005.05 & MTAR* & 0.71 & 0.98 & 0.98 & 1.00 & 1.00 & 1.01 \\
\hline \multirow[t]{4}{*}{ Lesotho } & national discount & 1999.03 & 2005.05 & MTAR* & 0.06 & 0.08 & 0.08 & 0.18 & 0.18 & 0.26 \\
\hline & SA discount & 1998.04 & 2005.05 & MTAR* & 0.26 & 0.37 & 0.37 & 0.53 & 0.53 & 0.54 \\
\hline & national T-bill & 1998.07 & 2005.05 & MTAR* & 0.13 & 0.31 & 0.45 & 0.49 & 0.61 & 0.66 \\
\hline & SA T-bill & 1998.06 & 2005.05 & MTAR* & 0.56 & 0.45 & 0.45 & 0.56 & 0.56 & 0.61 \\
\hline \multirow[t]{4}{*}{ Swaziland } & national discount & 1994.10 & 2005.05 & MTAR* & 0.87 & 0.87 & 0.87 & 0.87 & 0.87 & 0.86 \\
\hline & SA discount & 1992.10 & 2005.05 & MTAR0 & 0.37 & 0.66 & 0.65 & 0.77 & 0.78 & 0.75 \\
\hline & national T-bill & 2003.05 & 2005.05 & SYM & 0.56 & 0.87 & 0.87 & 0.88 & 0.88 & 0.88 \\
\hline & SA T-bill & 1992.11 & 2005.05 & MTAR* & 0.52 & 0.61 & 0.61 & 0.84 & 0.84 & 0.84 \\
\hline \multirow[t]{4}{*}{ Namibia } & national discount & 1995.11 & 2005.05 & STD & 0.26 & 0.37 & 0.37 & 0.38 & 0.38 & 0.38 \\
\hline & SA discount & 2000.01 & 2005.05 & STD & 0.07 & 0.08 & 0.08 & 0.08 & 0.08 & 0.08 \\
\hline & national T-bill & 1999.10 & 2005.05 & MTAR* & 0.04 & 0.31 & 0.46 & 0.42 & 0.63 & 0.58 \\
\hline & SA T-bill & 1999.12 & 2005.05 & MTAR* & 0.08 & 0.57 & 0.57 & 0.56 & 0.56 & 0.49 \\
\hline \multirow[t]{4}{*}{ Average respose of deposit rate to } & national discount & & & & 0.42 & 0.61 & 0.64 & 0.57 & 0.57 & 0.60 \\
\hline & SA discount & & & & 0.30 & 0.55 & 0.58 & 0.55 & 0.56 & 0.57 \\
\hline & national T-bill & & & & 0.36 & 0.62 & 0.69 & 0.70 & 0.78 & 0.78 \\
\hline & SA T-bill & & & & 0.45 & 0.64 & 0.65 & 0.68 & 0.68 & 0.69 \\
\hline \multicolumn{11}{|l|}{ Panel B: Prime Lending Rate } \\
\hline \multirow[t]{2}{*}{ South Africa } & national discount & 1991.01 & 2005.05 & BTAR* & 0.58 & 1.07 & 1.08 & 1.04 & 1.06 & 0.99 \\
\hline & national T-bill & 1997.06 & 2005.05 & MTAR* & 1.11 & 0.81 & 0.81 & 1.22 & 1.23 & 1.14 \\
\hline \multirow[t]{4}{*}{ Lesotho } & national discount & 2003.06 & 2005.05 & SYM & 0.46 & 1.34 & 1.34 & 0.98 & 0.98 & 1.01 \\
\hline & SA discount & 1999.01 & 2005.05 & SYM & 0.58 & 0.73 & 0.73 & 0.82 & 0.82 & 0.91 \\
\hline & national T-bill & 2003.06 & 2005.05 & MTAR* & 0.25 & 1.36 & 0.87 & 1.53 & 1.10 & 0.88 \\
\hline & SA T-bill & 1998.12 & 2005.05 & STD & 0.87 & 0.71 & 0.71 & 0.71 & 0.71 & 0.71 \\
\hline \multirow[t]{4}{*}{ Swaziland } & national discount & 2003.09 & 2005.05 & BTAR* & 1.00 & 1.00 & 1.00 & 1.00 & 1.00 & 1.00 \\
\hline & SA discount & 1995.03 & 2005.05 & MTAR* & 0.50 & 0.67 & 0.62 & 0.84 & 0.78 & 0.84 \\
\hline & national T-bill & 2003.06 & 2005.05 & MTAR* & 0.86 & 0.86 & 0.86 & 0.94 & 0.94 & 0.87 \\
\hline & SA T-bill & 1995.03 & 2005.05 & BTAR* & 0.53 & 0.80 & 0.48 & 1.07 & 0.57 & 0.93 \\
\hline \multirow[t]{4}{*}{ Namibia } & national discount & 1991.01 & 2005.05 & MTAR* & 0.13 & 0.68 & 0.68 & 0.76 & 0.76 & 0.85 \\
\hline & SA discount & 1994.09 & 2005.05 & TAR* & -0.08 & 0.74 & 0.77 & 0.74 & 0.76 & 0.89 \\
\hline & national T-bill & 1994.10 & 2005.05 & MTAR* & 0.43 & 0.44 & 0.44 & 0.84 & 0.84 & 0.95 \\
\hline & SA T-bill & 1994.10 & 2003.05 & MTAR* & 0.27 & 0.49 & 0.49 & 0.80 & 0.80 & 0.98 \\
\hline \multirow[t]{4}{*}{ Average respose of lendig rate to } & national discount & & & & 0.54 & 1.02 & 1.03 & 0.95 & 0.95 & 0.96 \\
\hline & SA discount & & & & 0.39 & 0.80 & 0.80 & 0.86 & 0.85 & 0.91 \\
\hline & national T-bill & & & & 0.66 & 0.87 & 0.75 & 1.13 & 1.03 & 0.96 \\
\hline & SA T-bill & & & & 0.69 & 0.70 & 0.62 & 0.95 & 0.83 & 0.94 \\
\hline
\end{tabular}

Note: The interim multipliers are reported for a $1 \%$ shock only. 
Table A1: Unit root tests which allow for the presense of a structural break

\begin{tabular}{|c|c|c|c|c|c|c|c|c|c|c|c|c|c|c|c|c|c|c|c|c|c|}
\hline \multirow[b]{3}{*}{ country } & \multirow[b]{3}{*}{ interest rate } & \multicolumn{8}{|c|}{ mean shift } & \multicolumn{8}{|c|}{ trend shift } & \multicolumn{4}{|c|}{ recursive } \\
\hline & & \multirow[b]{2}{*}{$\begin{array}{r}\min \\
\mathrm{t}(\text { level }) \\
\end{array}$} & \multirow[b]{2}{*}{$\begin{array}{r}\min \\
t(\text { diff }) \\
\end{array}$} & \multicolumn{2}{|c|}{$\mathrm{I}(?)$} & \multirow[b]{2}{*}{$\begin{array}{r}\max \\
\mathrm{F}(\text { level }) \\
\end{array}$} & \multirow[b]{2}{*}{$\begin{array}{r}\max \\
\mathrm{F} \text { (diff) } \\
\end{array}$} & \multicolumn{2}{|c|}{$\mathrm{I}(?)$} & \multirow[b]{2}{*}{$\begin{array}{r}\min \\
\mathrm{t}(\text { level }) \\
\end{array}$} & \multirow[b]{2}{*}{$\begin{array}{r}\min \\
t(\text { diff }) \\
\end{array}$} & \multicolumn{2}{|c|}{$\mathrm{I}(?)$} & \multirow[b]{2}{*}{$\begin{array}{r}\max \\
\mathrm{F}(\text { level })\end{array}$} & \multirow[b]{2}{*}{$\begin{array}{r}\max \\
\mathrm{F} \text { (diff) } \\
\end{array}$} & \multicolumn{2}{|c|}{$\mathrm{I}(?)$} & \multirow[b]{2}{*}{$\begin{array}{r}\min \\
\mathrm{t}(\text { level }) \\
\end{array}$} & \multirow[b]{2}{*}{$\begin{array}{r}\min \\
t(\text { diff }) \\
\end{array}$} & \multicolumn{2}{|c|}{$\mathrm{I}(?)$} \\
\hline & & & & $10 \%$ & $5 \%$ & & & $10 \%$ & $5 \%$ & & & $10 \%$ & $5 \%$ & & & $10 \%$ & $5 \%$ & & & $10 \%$ & $5 \%$ \\
\hline South Africa & deposit & -2.36 & -5.75 & 1 & 1 & 12.79 & 31.41 & 1 & 1 & -2.35 & -5.74 & 1 & 1 & 14.33 & 29.37 & 0 & 1 & -2.13 & -6.50 & 1 & 1 \\
\hline Lesotho & deposit & -2.06 & -8.44 & 1 & 1 & 9.03 & 47.91 & 1 & 1 & -1.94 & -8.44 & 1 & 1 & 5.55 & 51.10 & 1 & 1 & -1.83 & -9.52 & 1 & 1 \\
\hline Swaziland & deposit & -1.92 & -6.38 & 1 & 1 & 7.70 & 29.85 & 1 & 1 & -1.96 & -6.39 & 1 & 1 & 8.23 & 29.12 & 1 & 1 & -1.54 & -7.22 & 1 & 1 \\
\hline Namibia & deposit & -1.99 & -6.38 & 1 & 1 & 11.27 & 33.33 & 1 & 1 & -2.21 & -6.38 & 1 & 1 & 11.70 & 31.00 & 1 & 1 & -1.63 & -7.16 & 1 & 1 \\
\hline South Africa & prime lending & -2.34 & -5.51 & 1 & 1 & 8.68 & 26.64 & 1 & 1 & -2.33 & -5.51 & 1 & 1 & 8.91 & 25.50 & 1 & 1 & -1.96 & -6.25 & 1 & 1 \\
\hline Lesotho & prime lending & -2.90 & -10.00 & 1 & 1 & 6.55 & 69.29 & 1 & 1 & -2.87 & -10.00 & 1 & 1 & 5.76 & 70.34 & 1 & 1 & -2.39 & -11.26 & 1 & 1 \\
\hline Swaziland & prime lending & -1.90 & -6.09 & 1 & 1 & 7.63 & 27.11 & 1 & 1 & -2.09 & -6.06 & 1 & 1 & 9.38 & 26.26 & 1 & 1 & -1.22 & -6.87 & 1 & 1 \\
\hline Namibia & prime lending & -2.33 & -9.68 & 1 & 1 & 8.50 & 68.02 & 1 & 1 & -2.32 & -9.67 & 1 & 1 & 8.96 & 67.47 & 1 & 1 & -2.00 & -10.83 & 1 & 1 \\
\hline South Africa & discount & -2.38 & -5.95 & 1 & 1 & 8.30 & 29.14 & 1 & 1 & -2.36 & -5.96 & 1 & 1 & 8.53 & 28.00 & 1 & 1 & -1.87 & -6.76 & 1 & 1 \\
\hline Lesotho & discount & -2.45 & -8.63 & 1 & 1 & 6.69 & 51.65 & 1 & 1 & -2.44 & -8.62 & 1 & 1 & 5.85 & 52.15 & 1 & 1 & -2.30 & -9.70 & 1 & 1 \\
\hline Swaziland & discount & -2.01 & -6.18 & 1 & 1 & 7.00 & 27.54 & 1 & 1 & -2.01 & -6.14 & 1 & 1 & 8.93 & 26.82 & 1 & 1 & -1.20 & -6.93 & 1 & 1 \\
\hline Namibia & discount & -2.10 & -5.37 & 1 & 1 & 10.76 & 25.25 & 1 & 1 & -2.12 & -5.38 & 1 & 1 & 12.35 & 23.38 & 1 & 1 & -1.83 & -6.11 & 1 & 1 \\
\hline South Africa & t-bill & -2.63 & -5.86 & 1 & 1 & 11.99 & 31.48 & 1 & 1 & -2.62 & -5.87 & 1 & 1 & 13.77 & 29.58 & 0 & 1 & -2.51 & -6.64 & 1 & 1 \\
\hline Lesotho & t-bill & -2.14 & -8.56 & 1 & 1 & 6.90 & 52.25 & 1 & 1 & -2.14 & -8.55 & 1 & 1 & 7.42 & 51.67 & 1 & 1 & -2.07 & -9.57 & 1 & 1 \\
\hline Swaziland & t-bill & -1.83 & -7.74 & 1 & 1 & 6.40 & 40.10 & 1 & 1 & -1.75 & -7.72 & 1 & 1 & 5.50 & 39.79 & 1 & 1 & -1.72 & -8.62 & 1 & 1 \\
\hline Namibia & t-bill & -2.28 & -6.05 & 1 & 1 & 12.35 & 33.45 & 1 & 1 & -2.28 & -6.05 & 1 & 1 & 15.27 & 31.57 & 0 & 1 & -2.22 & -6.81 & 1 & 1 \\
\hline
\end{tabular}


Table A2: Structural Breaks in the Long-Run Relationship

\begin{tabular}{|c|c|c|c|}
\hline country & bank rate & supF & Breakpoint \\
\hline \multicolumn{4}{|c|}{ Panel A: Long-run relationship between national bank rate and national discount rate } \\
\hline South Africa & deposit & 54.05 & May-97 \\
\hline Lesotho & deposit & 298.95 & February-99 \\
\hline Swaziland & deposit & 450.47 & September-94 \\
\hline Namibia & deposit & 61.56 & October-95 \\
\hline South Africa & prime lending & 9.55 & August-01 insignificant \\
\hline Lesotho & prime lending & 44.54 & May-03 \\
\hline Swaziland & prime lending & 124.48 & August-03 \\
\hline Namibia & prime lending & 13.76 & September-92 insignificant \\
\hline \multicolumn{4}{|c|}{ Panel B: Long-run relationship between national bank rate and South African discount rate } \\
\hline South Africa & deposit & 54.05 & May-97 \\
\hline Lesotho & deposit & 143.95 & March-98 \\
\hline Swaziland & deposit & 17.70 & September-92 \\
\hline Namibia & deposit & 69.04 & December-99 \\
\hline South Africa & prime lending & 9.55 & August-01 insignificant \\
\hline Lesotho & prime lending & 70.45 & December-98 \\
\hline Swaziland & prime lending & 144.14 & February-95 \\
\hline Namibia & prime lending & 78.09 & August-94 \\
\hline \multicolumn{4}{|c|}{ Panel C: Long-run relationship between national bank rate and national T-bill rate } \\
\hline South Africa & deposit & 46.12 & August-98 \\
\hline Lesotho & deposit & 162.89 & June-98 \\
\hline Swaziland & deposit & 89.27 & April-03 \\
\hline Namibia & deposit & 34.48 & September-99 \\
\hline South Africa & prime lending & 65.25 & May-97 \\
\hline Lesotho & prime lending & 40.08 & May-03 \\
\hline Swaziland & prime lending & 54.82 & May-03 \\
\hline Namibia & prime lending & 60.42 & September-94 \\
\hline \multicolumn{4}{|c|}{ Panel B: Long-run relationship between national bank rate and South AfricanT-bill rate } \\
\hline South Africa & deposit & 46.12 & August-98 \\
\hline Lesotho & deposit & 152.47 & May-98 \\
\hline Swaziland & deposit & 60.72 & October-92 \\
\hline Namibia & deposit & 75.30 & November-99 \\
\hline South Africa & prime lending & 65.25 & May-97 \\
\hline Lesotho & prime lending & 69.42 & November-98 \\
\hline Swaziland & prime lending & 190.14 & February-95 \\
\hline Namibia & prime lending & 67.34 & September-94 \\
\hline
\end{tabular}


Table A3: The long-run relationship between bank rates and policy rate؛

\begin{tabular}{|c|c|c|c|c|c|c|c|c|c|c|c|c|}
\hline \multirow[b]{2}{*}{ country } & \multirow[b]{2}{*}{ bank rate } & \multicolumn{2}{|c|}{ sample period } & \multirow[b]{2}{*}{ obs } & \multicolumn{2}{|r|}{ intercept } & \multicolumn{2}{|r|}{ slope } & \multirow[b]{2}{*}{ DW } & \multirow[b]{2}{*}{ DF } & \multirow[b]{2}{*}{$\mathrm{ADF}$} & \multirow[b]{2}{*}{ coint? } \\
\hline & & start & end & & coeff & t-stat & coeff & t-stat & & & & \\
\hline \multicolumn{13}{|c|}{ Panel A: Relationship of national bank rate to national discount rat $\epsilon$} \\
\hline South Africa & deposit & 1991.01 & 2005.05 & 173 & -1.53 & -5.65 & 1.01 & 51.61 & 0.41 & -4.53 & -3.41 & yes \\
\hline South Africa & deposit & 1991.01 & 1997.05 & 77 & -3.64 & -6.06 & 1.18 & 29.32 & 0.45 & -3.04 & & yes \\
\hline South Africa & deposit & 1997.06 & 2005.05 & 96 & -0.71 & -3.02 & 0.91 & 50.74 & 0.83 & -5.05 & & yes \\
\hline South Africa & prime lending & 1991.01 & 2005.05 & 173 & 3.42 & 23.56 & 0.99 & 95.07 & 0.97 & -7.41 & -5.35 & yes \\
\hline Lesotho & deposit & 1991.01 & 2005.05 & 173 & 0.07 & 0.04 & 0.53 & 4.62 & 0.06 & -1.86 & -1.55 & no \\
\hline Lesotho & deposit & 1991.01 & 1999.02 & 98 & 3.40 & 2.04 & 0.48 & 4.64 & 0.17 & -2.11 & -2.22 & no \\
\hline Lesotho & deposit & 1999.03 & 2005.05 & 75 & 1.02 & 1.94 & 0.26 & 7.70 & 0.75 & -4.24 & -2.10 & yes \\
\hline Lesotho & prime lending & 1991.01 & 2005.05 & 173 & 2.83 & 3.29 & 0.89 & 16.50 & 0.46 & -4.85 & -2.76 & yes \\
\hline Lesotho & prime lending & 1991.01 & 2003.05 & 149 & 6.19 & 7.33 & 0.70 & 13.56 & 0.65 & -5.65 & -4.15 & yes \\
\hline Lesotho & prime lending & 2003.06 & 2005.05 & 24 & -0.90 & -0.76 & 1.01 & 11.72 & 1.00 & -2.73 & -3.52 & yes \\
\hline Swaziland & deposit & 1991.01 & 2005.05 & 173 & -2.17 & -8.50 & 0.86 & 43.59 & 0.04 & -1.65 & -1.69 & no \\
\hline Swaziland & deposit & 1991.01 & 1994.09 & 45 & -10.58 & -26.72 & 1.64 & 50.10 & 0.33 & -4.04 & -3.38 & yes \\
\hline Swaziland & deposit & 1994.10 & 2005.05 & 128 & -2.47 & -21.47 & 0.86 & 98.41 & 0.21 & -2.56 & -1.99 & no \\
\hline Swaziland & prime lending & 1991.01 & 2005.05 & 173 & 3.56 & 64.55 & 0.96 & 224.29 & 0.39 & -5.12 & -3.70 & yes \\
\hline Swaziland & prime lending & 1991.01 & 2003.08 & 152 & 3.05 & 59.76 & 1.00 & 262.02 & 0.84 & -7.98 & & yes \\
\hline Swaziland & prime lending & 2003.09 & 2005.05 & 21 & 3.50 & 16487030694366.30 & 1.00 & 37126738274667.90 & 0.01 & -2.56 & & no \\
\hline Namibia & deposit & 1991.01 & 2005.05 & 173 & 1.40 & 5.49 & 0.59 & 34.43 & 0.19 & -2.83 & -2.31 & no \\
\hline Namibia & deposit & 1991.01 & 1995.10 & 58 & -1.50 & -3.42 & 0.72 & 27.99 & 1.52 & -5.79 & -5.30 & yes \\
\hline Namibia & deposit & 1995.11 & 2005.05 & 115 & 0.81 & 3.24 & 0.66 & 36.32 & 0.23 & -2.54 & -2.79 & no \\
\hline Namibia & prime lending & 1991.01 & 2005.05 & 173 & 5.05 & 16.44 & 0.85 & 41.41 & 0.68 & -6.11 & -4.17 & yes \\
\hline \multicolumn{13}{|c|}{ Panel B: Relationship of national bank rate to South African discount rate } \\
\hline South Africa & deposit & 1991.01 & 2005.05 & 173 & -1.53 & -5.65 & 1.01 & 51.61 & $\overline{0.41}$ & -4.53 & -3.41 & yes \\
\hline South Africa & deposit & 1991.01 & 1997.05 & 77 & -3.64 & -6.06 & 1.18 & 29.32 & 0.45 & -3.04 & & yes \\
\hline South Africa & deposit & 1997.06 & 2005.05 & 96 & -0.71 & -3.02 & 0.91 & 50.74 & 0.83 & -5.05 & & yes \\
\hline South Africa & prime lending & 1991.01 & 2005.05 & 173 & 3.42 & 23.56 & 0.99 & 95.07 & 0.97 & -7.41 & -5.35 & yes \\
\hline Lesotho & deposit & 1991.01 & 2005.05 & 173 & -3.29 & -4.82 & 0.87 & 17.68 & 0.14 & -2.43 & & no \\
\hline Lesotho & deposit & 1991.01 & 1998.03 & 87 & -2.79 & -2.00 & 0.93 & 10.05 & 0.22 & -2.24 & -2.47 & no \\
\hline Lesotho & deposit & 1998.04 & 2005.05 & 86 & -0.76 & -2.25 & 0.54 & 20.25 & 0.68 & -4.36 & -3.39 & yes \\
\hline Lesotho & prime lending & 1991.01 & 2005.05 & 173 & 8.02 & 18.69 & 0.66 & 21.31 & 0.63 & -5.61 & -2.29 & yes \\
\hline Lesotho & prime lending & 1991.01 & 1998.12 & 96 & 3.95 & 5.07 & 0.88 & 17.69 & 1.43 & -7.20 & -3.87 & yes \\
\hline Lesotho & prime lending & 1999.01 & 2005.05 & 77 & 5.96 & 15.99 & 0.91 & 27.91 & 0.53 & -3.51 & & yes \\
\hline Swaziland & deposit & 1991.01 & 2005.05 & 173 & -1.26 & -5.26 & 0.73 & 42.66 & 0.29 & -4.22 & & yes \\
\hline Swaziland & deposit & 1991.01 & 1992.09 & 21 & 13.53 & 14.51 & -0.17 & -3.04 & 0.20 & -2.08 & -1.89 & no \\
\hline Swaziland & deposit & 1992.10 & 2005.05 & 152 & -1.49 & -6.19 & 0.75 & 42.37 & 0.32 & -3.68 & & yes \\
\hline Swaziland & prime lending & 1991.01 & 2005.05 & 173 & 5.53 & 15.28 & 0.75 & 28.73 & 0.13 & -3.52 & & yes \\
\hline Swaziland & prime lending & 1991.01 & 1995.02 & 50 & 9.41 & 23.59 & 0.40 & 14.49 & 0.44 & -3.43 & & yes \\
\hline Swaziland & prime lending & 1995.03 & 2005.05 & 123 & 4.79 & 18.20 & 0.84 & 43.46 & 0.31 & -3.16 & -4.23 & yes \\
\hline Namibia & deposit & 1991.01 & 2005.05 & 173 & 0.37 & 1.31 & 0.70 & 34.20 & 0.26 & -3.34 & & no \\
\hline Namibia & deposit & 1991.01 & 1999.12 & 108 & 1.77 & 4.36 & 0.63 & 23.95 & 0.49 & -3.77 & & yes \\
\hline Namibia & deposit & 2000.01 & 2005.05 & 65 & 3.50 & 8.15 & 0.36 & 9.11 & 0.21 & -1.96 & -1.60 & no \\
\hline Namibia & prime lending & 1991.01 & 2005.05 & 173 & 4.15 & 8.90 & 0.97 & 29.02 & 0.44 & -4.90 & -3.57 & yes \\
\hline Namibia & prime lending & 1991.01 & 1994.08 & 44 & 3.48 & 3.78 & 1.13 & 18.00 & 0.95 & -3.71 & -4.44 & yes \\
\hline Namibia & prime lending & 1994.09 & 2005.05 & 129 & 4.69 & 12.52 & 0.89 & 32.50 & 0.78 & -5.56 & -3.73 & yes \\
\hline \multicolumn{13}{|c|}{ Panel C: Relationship of national bank rate to national T-bill rat $\epsilon$} \\
\hline $\begin{array}{l}\text { South Africa } \\
\end{array}$ & deposit & 1991.01 & 2005.05 & 173 & -1.36 & -7.59 & 1.09 & 77.43 & 0.98 & -7.45 & -4.70 & $\overline{\text { yes }}$ \\
\hline South Africa & deposit & 1991.01 & 1998.08 & 92 & -0.27 & -0.83 & 1.03 & 45.25 & 1.51 & -7.18 & & yes \\
\hline South Africa & deposit & 1998.09 & 2005.05 & 81 & -0.79 & -4.38 & 1.01 & 60.94 & 0.57 & -3.92 & -2.87 & yes \\
\hline South Africa & prime lending & 1991.01 & 2005.05 & 173 & 3.92 & 20.44 & 1.05 & 69.36 & 0.50 & -5.12 & -3.33 & yes \\
\hline South Africa & prime lending & 1991.01 & 1997.05 & 77 & 6.91 & 18.76 & 0.82 & 31.06 & 0.57 & -3.52 & -3.36 & yes \\
\hline South Africa & prime lending & 1997.06 & 2005.05 & 96 & 2.91 & 18.95 & 1.14 & 87.03 & 1.28 & -6.70 & & yes \\
\hline
\end{tabular}


Table A3: The long-run relationship between bank rates and policy rate؛

\begin{tabular}{|c|c|c|c|c|c|c|c|c|c|c|c|c|}
\hline \multirow[b]{2}{*}{ country } & \multirow[b]{2}{*}{ bank rate } & \multicolumn{2}{|c|}{ sample period } & \multirow[b]{2}{*}{ obs } & \multicolumn{2}{|c|}{ intercept } & \multicolumn{2}{|c|}{ slope } & \multirow[b]{2}{*}{ DW } & \multirow[b]{2}{*}{ DF } & \multirow[b]{2}{*}{ ADF } & \multirow[b]{2}{*}{ coint? } \\
\hline & & start & end & & coeff & t-stat & coeff & t-stat & & & & \\
\hline Lesotho & deposit & 1991.01 & 2005.05 & 173 & -3.12 & $\begin{array}{l}-3.96 \\
\end{array}$ & 0.97 & 15.05 & 0.22 & -3.13 & -1.97 & no \\
\hline Lesotho & deposit & 1991.01 & 1998.06 & 90 & 1.97 & 1.99 & 0.70 & 9.36 & 0.28 & -2.58 & & no \\
\hline Lesotho & deposit & 1998.07 & 2005.05 & 83 & -1.52 & -3.40 & 0.66 & 16.44 & 0.77 & -4.33 & -2.91 & yes \\
\hline Lesotho & prime lending & 1991.01 & 2005.05 & 173 & 8.01 & 15.98 & 0.74 & 18.19 & 0.50 & -4.89 & -1.89 & yes \\
\hline Lesotho & prime lending & 1991.01 & 2003.05 & 149 & 10.19 & 19.69 & 0.59 & 14.49 & 0.71 & -5.62 & -2.45 & yes \\
\hline Lesotho & prime lending & 2003.06 & 2005.05 & 24 & 4.98 & 10.66 & 0.88 & 17.48 & 0.65 & -2.03 & & yes \\
\hline Swaziland & deposit & 1991.01 & 2005.05 & 173 & -0.63 & -1.88 & 0.89 & 28.65 & 0.38 & -4.07 & -3.06 & yes \\
\hline Swaziland & deposit & 1991.01 & 2003.04 & 148 & 0.79 & 2.84 & 0.78 & 31.25 & 0.60 & -5.03 & & yes \\
\hline Swaziland & deposit & 2003.05 & 2005.05 & 25 & -2.25 & -5.58 & 0.88 & 18.83 & 2.81 & -10.69 & & yes \\
\hline Swaziland & prime lending & 1991.01 & 2005.05 & 173 & 6.18 & 14.31 & 0.90 & 22.53 & 0.24 & -3.31 & -2.71 & no \\
\hline Swaziland & prime lending & 1991.01 & 2003.05 & 149 & 7.83 & 19.38 & 0.78 & 21.46 & 0.28 & -3.55 & -2.87 & yes \\
\hline Swaziland & prime lending & 2003.60 & 2005.05 & 24 & 4.44 & 9.66 & 0.87 & 16.14 & 1.99 & -6.08 & -4.13 & yes \\
\hline Namibia & deposit & 1991.01 & 2005.05 & 173 & 0.37 & 1.70 & 0.76 & 45.41 & 0.37 & -4.10 & -4.64 & yes \\
\hline Namibia & deposit & 1991.01 & 1999.09 & 105 & 2.33 & 6.30 & 0.63 & 25.05 & 0.48 & -3.69 & -4.10 & yes \\
\hline Namibia & deposit & 1999.10 & 2005.05 & 68 & 1.83 & 4.25 & 0.58 & 13.14 & 0.31 & -2.33 & -2.44 & no \\
\hline Namibia & prime lending & 1991.01 & 2005.05 & 173 & 4.43 & 10.07 & 1.03 & 30.15 & 0.42 & -4.77 & -3.63 & yes \\
\hline Namibia & prime lending & 1991.01 & 1994.09 & 45 & 5.58 & 6.34 & 1.05 & 16.41 & 0.74 & -3.32 & -3.50 & yes \\
\hline Namibia & prime lending & 1994.10 & 2005.05 & 128 & 4.80 & 12.81 & 0.95 & 32.20 & 0.69 & -5.14 & -3.31 & yes \\
\hline \multicolumn{13}{|c|}{ Panel D: Relationship of national bank rate to South African T-bill rate } \\
\hline South Africa & deposit & 1991.01 & 2005.05 & 173 & -1.36 & -7.59 & 1.09 & 77.43 & 0.98 & -7.45 & -4.70 & $\overline{\text { yes }}$ \\
\hline South Africa & deposit & 1991.01 & 1998.08 & 92 & -0.27 & -0.83 & 1.03 & 45.25 & 1.51 & -7.18 & & yes \\
\hline South Africa & deposit & 1998.09 & 2005.05 & 81 & -0.79 & -4.38 & 1.01 & 60.94 & 0.57 & -3.92 & -2.87 & yes \\
\hline South Africa & prime lending & 1991.01 & 2005.05 & 173 & 3.92 & 20.44 & 1.05 & 69.36 & 0.50 & -5.12 & -3.33 & yes \\
\hline South Africa & prime lending & 1991.01 & 1997.05 & 77 & 6.91 & 18.76 & 0.82 & 31.06 & 0.57 & -3.52 & -3.36 & yes \\
\hline South Africa & prime lending & 1997.06 & 2005.05 & 96 & 2.91 & 18.95 & 1.14 & 87.03 & 1.28 & -6.70 & & yes \\
\hline Lesotho & deposit & 1991.01 & 2005.05 & 173 & -3.46 & -5.71 & 0.97 & 20.26 & 0.18 & -2.82 & & no \\
\hline Lesotho & deposit & 1991.01 & 1998.05 & 89 & -1.11 & -1.14 & 0.89 & 12.61 & 0.27 & -2.58 & -2.69 & no \\
\hline Lesotho & deposit & 1998.06 & 2005.05 & 84 & -0.92 & -2.78 & 0.61 & 20.79 & 0.81 & -4.84 & & yes \\
\hline Lesotho & prime lending & 1991.01 & 2005.05 & 173 & 8.36 & 19.57 & 0.69 & 20.59 & 0.52 & -4.99 & -1.86 & yes \\
\hline Lesotho & prime lending & 1991.01 & 1998.11 & 95 & 5.52 & 8.61 & 0.85 & 18.96 & 1.42 & -7.12 & -3.56 & yes \\
\hline Lesotho & prime lending & 1998.12 & 2005.05 & 78 & 5.53 & 11.21 & 1.04 & 22.04 & 0.24 & -2.39 & & no \\
\hline Swaziland & deposit & 1991.01 & 2005.05 & 173 & -0.83 & -3.13 & 0.77 & 36.93 & 0.25 & -4.17 & -5.12 & yes \\
\hline Swaziland & deposit & 1991.01 & 1992.10 & 22 & 11.39 & 19.80 & -0.05 & -1.23 & 0.29 & -1.68 & 0.41 & no \\
\hline Swaziland & deposit & 1992.11 & 2005.05 & 151 & -1.55 & -6.73 & 0.84 & 44.48 & 0.43 & -4.29 & -5.73 & yes \\
\hline Swaziland & prime lending & 1991.01 & 2005.05 & 173 & 6.13 & 15.31 & 0.77 & 24.45 & 0.12 & -3.43 & -3.46 & yes \\
\hline Swaziland & prime lending & 1991.01 & 1995.02 & 50 & 11.00 & 29.41 & 0.31 & 11.23 & 0.24 & -2.36 & -2.21 & no \\
\hline Swaziland & prime lending & 1995.03 & 2005.05 & 123 & 4.66 & 17.18 & 0.93 & 42.65 & 0.45 & -3.93 & -5.36 & yes \\
\hline Namibia & deposit & 1991.01 & 2005.05 & 173 & 0.54 & 2.14 & 0.76 & 37.99 & 0.26 & -3.44 & -3.71 & yes \\
\hline Namibia & deposit & 1995.09 & 1999.11 & 107 & 2.83 & 8.57 & 0.61 & 26.49 & 0.48 & -3.68 & -4.18 & yes \\
\hline Namibia & deposit & 1999.12 & 2005.05 & 66 & 2.66 & 6.37 & 0.49 & 11.40 & 0.23 & -2.15 & -2.30 & no \\
\hline Namibia & prime lending & 1991.01 & 2005.05 & 173 & 4.57 & 9.96 & 1.03 & 28.62 & 0.40 & -4.51 & -3.18 & yes \\
\hline Namibia & prime lending & 1991.01 & 1994.09 & 45 & 7.28 & 10.87 & 0.95 & 19.09 & 0.89 & -3.53 & -3.65 & yes \\
\hline Namibia & prime lending & 1994.10 & 2005.05 & 128 & 4.61 & 11.41 & 0.98 & 30.27 & 0.67 & -5.05 & -3.28 & yes \\
\hline
\end{tabular}

The following test statistics are reported: Durbin Watson (DW), Dickey Fuller (DF), Augmented Dickey Fuller with optimal lag length selected by AIC criteria based on all models up to 4 lags $(\mathrm{ADF}(\mathrm{k} 4))$ or 12 lags $(\mathrm{ADF}(\mathrm{k} 12))$. The critical values at the $1 \%, 5 \%$, and $10 \%$ level for 100 observations are as follows: $0.511,0.386$, and 0.322 for DW, 4.07, 3.37, and 3.03 for $\mathrm{DF}, 3.77,3.17$, and 2.84 for $\mathrm{ADF}(\mathrm{k})$. Cointegration is considered to exist if at least 2 test statistics are significant at $10 \%$ level or 1 test statistic at $5 \%$ level. 
optimal

Asymmetric Cointegratior

symmetric Pass-through

\begin{tabular}{l} 
country bankrate $\quad$ start end o \\
\hline Panel A: Relationship of national bank rate to national discount rat
\end{tabular}

\begin{tabular}{|c|c|c|c|c|c|c|c|c|c|c|c|c|c|c|c|c|c|c|}
\hline South Africa & deposit & 1991.01 & 2005.05 & 173 & 625.00 & 620.09 & 620.62 & 621.32 & 614.01 & 614.01 & MTAR* & 11.26 & 11.06 & & & yes,asym & yes & MTAR* \\
\hline South Africa & deposit & 1991.01 & 1997.05 & 77 & 185.99 & 185.20 & 181.87 & 186.12 & 182.75 & 181.87 & BTAR* & 4.85 & 5.25 & 0.62 & 6.26 & no & yes & SYM \\
\hline South Africa & deposit & 1997.06 & 2005.05 & 96 & 318.56 & 316.66 & 315.72 & 314.84 & 308.30 & 308.30 & MTAR* & 16.25 & 10.66 & & & yes,asym & yes & MTAR* \\
\hline South Africa & prime lending & 1991.01 & 2005.05 & 173 & 532.94 & 531.98 & 518.33 & 533.56 & 530.19 & 518.33 & BTAR* & 11.01 & 16.67 & 0.78 & 16.94 & yes,asym & yes & BTAR* \\
\hline Lesotho & deposit & 1991.01 & 2005.05 & 173 & 797.71 & 796.46 & 795.71 & 797.80 & 790.11 & 790.11 & MTAR* & 4.84 & 7.74 & & & no & no & STD \\
\hline Lesotho & deposit & 1991.01 & 1999.02 & 98 & 382.89 & 381.76 & 370.72 & 382.88 & 382.39 & 370.72 & BTAR* & 5.96 & 13.97 & 0.00 & 14.14 & no & no & STD \\
\hline Lesotho & deposit & 1999.03 & 2005.05 & 75 & 240.65 & 235.72 & 235.56 & 240.85 & 232.14 & 232.14 & MTAR* & 21.39 & 14.52 & & & yes,asym & yes & MTAR* \\
\hline Lesotho & prime lending & 1991.01 & 2005.05 & 173 & 846.55 & 841.26 & 843.08 & 849.81 & 825.23 & 825.23 & MTAR* & 16.22 & 26.92 & & & yes,asym & yes & MTAR* \\
\hline Lesotho & prime lending & 1991.01 & 2003.05 & 149 & 706.64 & 701.46 & 702.28 & 706.25 & 679.31 & 679.31 & MTAR* & 20.73 & 31.38 & & & yes,asym & yes & MTAR* \\
\hline Lesotho & prime lending & 2003.06 & 2005.05 & 24 & 43.55 & 42.96 & 42.80 & 43.61 & 31.70 & 31.70 & MTAR* & 18.91 & 13.50 & & & yes,asym & yes & MTAR* \\
\hline Swaziland & deposit & 1991.01 & 2005.05 & 173 & 203.89 & 191.49 & 180.50 & 189.83 & 178.73 & 178.73 & MTAR* & 16.41 & 26.56 & & & yes,asym & no & MTAR* \\
\hline Swaziland & deposit & 1991.01 & 1994.09 & 45 & -44.44 & -50.12 & -48.19 & -80.75 & -80.75 & -80.75 & MTAR0 & 44.67 & 68.65 & & & yes,asym & yes & MTAR0 \\
\hline Swaziland & deposit & 1994.10 & 2005.05 & 128 & 115.54 & 107.21 & 114.59 & 114.11 & 102.42 & 102.42 & MTAR* & 8.99 & 14.04 & & & yes,asym & no & MTAR* \\
\hline Swaziland & prime lending & 1991.01 & 2005.05 & 173 & 49.77 & 48.17 & 45.17 & 48.00 & 38.22 & 38.22 & MTAR* & 13.31 & 12.06 & & & yes,asym & yes & MTAR* \\
\hline Swaziland & prime lending & 1991.01 & 2003.08 & 152 & -3.88 & -4.87 & -5.47 & -6.03 & -6.32 & -6.32 & MTAR* & 21.86 & 6.03 & & & yes,asym & yes & MTAR* \\
\hline Swaziland & prime lending & 2003.09 & 2005.05 & 21 & -50.69 & -55.94 & -70.64 & -55.02 & -59.81 & -70.64 & BTAR* & 42.27 & 28.08 & 18.15 & 32.54 & yes,asym & no & BTAR* \\
\hline Namibia & deposit & 1991.01 & 2005.05 & 173 & 523.73 & 518.76 & 509.71 & 518.70 & 514.47 & 509.71 & BTAR* & 7.04 & 12.39 & 0.76 & 16.09 & yes,asym & no & BTAR* \\
\hline Namibia & deposit & 1991.01 & 1995.10 & 58 & 106.95 & 105.83 & 105.80 & 106.76 & 106.10 & 105.80 & BTAR* & 2.91 & 2.82 & 0.01 & 2.82 & no & yes & SYM \\
\hline Namibia & deposit & 1995.11 & 2005.05 & 115 & 317.58 & 315.27 & 311.90 & 315.67 & 314.32 & 311.90 & BTAR* & 5.10 & 7.75 & 0.14 & 7.69 & no & no & STD \\
\hline Namibia & prime lending & 1991.01 & 2005.05 & 173 & 761.56 & 759.96 & 755.45 & 761.17 & 756.92 & 755.45 & BTAR* & 8.13 & 8.00 & 0.04 & 7.95 & yes,asym & yes & BTAR* \\
\hline \multicolumn{19}{|c|}{ Panel B: Relationship of national bank rate to South African discount rat } \\
\hline South Africa & deposit & 1991.01 & 2005.05 & 173 & 625.00 & 620.09 & 620.62 & 621.32 & 614.01 & 614.01 & MTAR* & 11.26 & 11.06 & & & yes,asym & yes & MTAR* \\
\hline South Africa & deposit & 1991.01 & 1997.05 & 77 & 185.99 & 185.20 & 181.87 & 186.12 & 182.75 & 181.87 & BTAR* & 4.85 & 5.25 & 0.62 & 6.26 & no & yes & SYM \\
\hline South Africa & deposit & 1997.06 & 2005.05 & 96 & 318.56 & 316.66 & 315.72 & 314.84 & 308.30 & 308.30 & MTAR* & 16.25 & 10.66 & & & yes,asym & yes & MTAR* \\
\hline South Africa & prime lending & 1991.01 & 2005.05 & 173 & 532.94 & 531.98 & 518.33 & 533.56 & 530.19 & 518.33 & BTAR* & 11.01 & 16.67 & 0.78 & 16.94 & yes,asym & yes & BTAR* \\
\hline Lesotho & deposit & 1991.01 & 2005.05 & 173 & 776.22 & 775.44 & 770.22 & 775.63 & 772.47 & 770.22 & BTAR* & 4.45 & 7.90 & 0.11 & 7.86 & no & no & STD \\
\hline Lesotho & deposit & 1991.01 & 1998.03 & 87 & 311.16 & 306.28 & 300.36 & 310.52 & 308.06 & 300.36 & BTAR* & 6.12 & 8.06 & 2.00 & 13.19 & no & no & STD \\
\hline Lesotho & deposit & 1998.04 & 2005.05 & 86 & 326.03 & 324.34 & 322.58 & 323.12 & 315.12 & 315.12 & MTAR* & 16.49 & 11.36 & & & yes,asym & yes & MTAR* \\
\hline Lesotho & prime lending & 1991.01 & 2005.05 & 173 & 824.28 & 821.25 & 814.03 & 823.30 & 805.18 & 805.18 & MTAR* & 12.33 & 19.61 & & & yes,asym & yes & MTAR* \\
\hline Lesotho & prime lending & 1991.01 & 1998.12 & 96 & 430.79 & 429.96 & 426.97 & 431.40 & 425.09 & 425.09 & MTAR* & 7.42 & 6.12 & & & yes,asym & yes & MTAR* \\
\hline Lesotho & prime lending & 1999.01 & 2005.05 & 77 & 229.04 & 227.61 & 227.08 & 229.25 & 227.86 & 227.08 & BTAR* & 4.27 & 3.51 & 0.23 & 4.11 & no & yes & SYM \\
\hline Swaziland & deposit & 1991.01 & 2005.05 & 173 & 533.23 & 532.86 & 531.74 & 514.16 & 514.16 & 514.16 & MTAR0 & 19.89 & 19.94 & & & yes,asym & yes & MTAR0 \\
\hline Swaziland & deposit & 1991.01 & 1992.09 & 21 & -39.73 & -42.14 & -42.17 & -40.18 & -43.05 & -43.05 & MTAR* & 4.04 & 2.62 & & & no & no & STD \\
\hline Swaziland & deposit & 1992.10 & 2005.05 & 152 & 477.06 & 476.38 & 476.16 & 468.53 & 468.53 & 468.53 & MTAR0 & 14.66 & 12.74 & & & yes,asym & yes & MTAR0 \\
\hline Swaziland & prime lending & 1991.01 & 2005.05 & 173 & 545.65 & 544.16 & 534.06 & 537.06 & 532.97 & 532.97 & MTAR* & 11.71 & 13.04 & & & yes,asym & yes & MTAR* \\
\hline Swaziland & prime lending & 1991.01 & 1995.02 & 50 & 49.52 & 44.22 & 43.37 & 44.25 & 38.02 & 38.02 & MTAR* & 13.01 & 12.86 & & & yes,asym & yes & MTAR* \\
\hline Swaziland & prime lending & 1995.03 & 2005.05 & 123 & 365.43 & 364.52 & 363.27 & 362.88 & 361.57 & 361.57 & MTAR* & 11.22 & 3.85 & & & yes,asym & yes & MTAR* \\
\hline Namibia & deposit & 1991.01 & 2005.05 & 173 & 582.20 & 580.69 & 575.16 & 582.10 & 570.54 & 570.54 & MTAR* & 9.33 & 11.81 & & & yes,asym & no & MTAR* \\
\hline Namibia & deposit & 1991.01 & 1999.12 & 108 & 302.92 & 301.72 & 297.11 & 303.19 & 301.09 & 297.11 & BTAR* & 5.65 & 7.29 & 0.33 & 7.65 & no & yes & SYM \\
\hline Namibia & deposit & 2000.01 & 2005.05 & 65 & 129.96 & 126.94 & 127.63 & 129.01 & 123.50 & 123.50 & MTAR* & 5.14 & 7.02 & & & no & no & STD \\
\hline Namibia & prime lending & 1991.01 & 2005.05 & 173 & 807.57 & 805.97 & 802.77 & 806.24 & 802.64 & 802.64 & MTAR* & 9.09 & 5.47 & & & yes,asym & yes & MTAR* \\
\hline Namibia & prime lending & 1991.01 & 1994.08 & 44 & 116.79 & 116.31 & 113.17 & 112.56 & 112.56 & 112.56 & MTAR0 & 6.04 & 4.20 & & & yes,asym & yes & MTAR0 \\
\hline Namibia & prime lending & 1994.09 & 2005.05 & 129 & 578.28 & 576.04 & 576.20 & 577.93 & 577.59 & 576.04 & TAR* & 8.86 & 3.46 & & & yes,asym & yes & TAR* \\
\hline
\end{tabular}

Namibia $\begin{array}{lll}\text { prime lending } & 1994.09 & 2005.05\end{array}$

$\begin{array}{llllllll}129 & 578.28 & 576.04 & 576.20 & 577.93 & 577.59 & 576.04\end{array}$

yes, asym 

$\begin{array}{ccc} & \text { optimal } & \text { Asymmetric Cointegratior } \\ & \text { min AIC TAR model } \mathrm{H}_{0}: \Sigma \mathrm{j} \rho_{\mathrm{j}}=0 & \mathrm{H}_{0}: \rho_{1}=\rho_{2} \mathrm{H}_{0}: \rho_{1}=\rho_{3} \mathrm{H}_{0}: \rho_{2}=\rho_{3}\end{array}$ \begin{tabular}{ccc} 
& optimal & \multicolumn{2}{c}{ Asymmetric Cointegratior } \\
& min AIC TAR model $\mathrm{H}_{0}: \Sigma \mathrm{j} \rho_{\mathrm{j}}=0$ & $\mathrm{H}_{0}: \rho_{1}=\rho_{2} \quad \mathrm{H}_{0}: \rho_{1}=\rho_{3} \mathrm{H}_{0}: \rho_{2}=\rho_{3}$
\end{tabular} symmetric Pass-through country

bankrate start end obs $\mathrm{TAR}^{0}$ AIC MTAR $^{*}$

coint? coint? model

\begin{tabular}{|c|c|c|c|c|c|c|c|c|c|c|c|c|c|c|c|c|c|c|}
\hline South Africa & deposit & 1991.01 & 2005.05 & 173 & 610.87 & 607.94 & 609.27 & 610.94 & 602.12 & 602.12 & MTAR* & 10.80 & 8.80 & & & yes,asym & yes & MTAR* \\
\hline South Africa & deposit & 1991.01 & 1998.08 & 92 & 264.99 & 260.14 & 259.41 & 265.24 & 253.60 & 253.60 & MTAR* & 13.39 & 13.38 & & & yes,asym & yes & MTAR* \\
\hline South Africa & deposit & 1998.09 & 2005.05 & 81 & 180.54 & 172.72 & 174.00 & 180.77 & 169.68 & 169.68 & MTAR* & 14.98 & 13.82 & & & yes,asym & yes & MTAR* \\
\hline South Africa & prime lending & 1991.01 & 2005.05 & 173 & 536.40 & 535.29 & 529.65 & 535.11 & 522.21 & 522.21 & MTAR* & 12.09 & 14.42 & & & yes,asym & yes & MTAR* \\
\hline South Africa & prime lending & 1991.01 & 1997.05 & 77 & 161.83 & 161.50 & 161.33 & 161.98 & 158.54 & 158.54 & MTAR* & 3.51 & 3.26 & & & no & yes & SYM \\
\hline South Africa & prime lending & 1997.06 & 2005.05 & 96 & 251.72 & 250.50 & 246.89 & 248.96 & 246.32 & 246.32 & MTAR* & 17.86 & 5.54 & & & yes,asym & yes & MTAR* \\
\hline Lesotho & deposit & 1991.01 & 2005.05 & 173 & 873.25 & 872.35 & 869.18 & 872.98 & 870.64 & 869.18 & BTAR* & 3.26 & 5.78 & 0.40 & 5.90 & no & no & STD \\
\hline Lesotho & deposit & 1991.01 & 1998.06 & 90 & 355.67 & 352.75 & 352.01 & 356.22 & 355.22 & 352.01 & BTAR* & 3.47 & 0.10 & 4.94 & 5.05 & no & no & STD \\
\hline Lesotho & deposit & 1998.07 & 2005.05 & 83 & 324.00 & 323.66 & 324.23 & 323.89 & 313.21 & 313.21 & MTAR* & 10.54 & 11.32 & & & yes,asym & yes & MTAR* \\
\hline Lesotho & prime lending & 1991.01 & 2005.05 & 173 & 828.11 & 824.37 & 823.78 & 826.88 & 812.98 & 812.98 & MTAR* & 9.46 & 15.94 & & & yes,asym & yes & MTAR* \\
\hline Lesotho & prime lending & 1991.01 & 2003.05 & 149 & 700.64 & 697.92 & 697.64 & 700.11 & 684.28 & 684.28 & MTAR* & 11.12 & 16.74 & & & yes,asym & yes & MTAR* \\
\hline Lesotho & prime lending & 2003.06 & 2005.05 & 24 & 22.30 & 21.76 & 21.45 & 21.87 & 16.39 & 16.39 & MTAR* & 6.35 & 6.14 & & & yes,asym & yes & MTAR* \\
\hline Swaziland & deposit & 1991.01 & 2005.05 & 173 & 695.05 & 693.18 & 693.89 & 695.43 & 689.13 & 689.13 & MTAR* & 6.93 & 6.21 & & & yes,asym & yes & MTAR* \\
\hline Swaziland & deposit & 1991.01 & 2003.04 & 148 & 548.22 & 546.56 & 544.57 & 547.83 & 546.23 & 544.57 & BTAR* & 7.05 & 5.64 & 0.21 & 5.42 & yes,asym & yes & BTAR* \\
\hline Swaziland & deposit & 2003.05 & 2005.05 & 25 & 14.37 & 12.52 & 3.92 & 11.20 & 9.58 & 3.92 & BTAR* & 20.10 & 9.18 & 0.11 & 13.75 & yes,asym & yes & BTAR* \\
\hline Swaziland & prime lending & 1991.01 & 2005.05 & 173 & 702.72 & 700.38 & 698.26 & 703.43 & 698.52 & 698.26 & BTAR* & 4.12 & 6.31 & 0.88 & 6.31 & no & no & STD \\
\hline Swaziland & prime lending & 1991.01 & 2003.05 & 149 & 555.05 & 553.95 & 553.62 & 553.84 & 552.27 & 552.27 & MTAR* & 5.23 & 2.80 & & & no & yes & SYM \\
\hline Swaziland & prime lending & 2003.06 & 2005.05 & 24 & 29.40 & 29.14 & 30.63 & 29.19 & 16.97 & 16.97 & MTAR* & 26.50 & 15.23 & & & yes,asym & yes & MTAR* \\
\hline Namibia & deposit & 1991.01 & 2005.05 & 173 & 544.10 & 543.01 & 542.28 & 543.87 & 539.68 & 539.68 & MTAR* & 10.97 & 4.37 & & & yes,asym & yes & MTAR* \\
\hline Namibia & deposit & 1991.01 & 1999.09 & 105 & 266.93 & 265.70 & 265.90 & 264.48 & 259.89 & 259.89 & MTAR* & 9.54 & 6.88 & & & yes,asym & yes & MTAR* \\
\hline Namibia & deposit & 1999.10 & 2005.05 & 68 & 131.15 & 129.90 & 128.82 & 126.23 & 121.28 & 121.28 & MTAR* & 7.40 & 10.56 & & & yes,asym & no & MTAR* \\
\hline Namibia & prime lending & 1991.01 & 2005.05 & 173 & 789.00 & 788.14 & 784.31 & 788.00 & 787.34 & 784.31 & BTAR* & 6.10 & 6.45 & 0.05 & 6.55 & yes,asym & yes & BTAR* \\
\hline Namibia & prime lending & 1991.01 & 1994.09 & 45 & 127.75 & 125.77 & 125.61 & 127.76 & 123.42 & 123.42 & MTAR* & 5.43 & 3.99 & & & no & yes & SYM \\
\hline Namibia & prime lending & 1994.10 & 2005.05 & 128 & 562.25 & 561.66 & 561.50 & 561.84 & 557.57 & 557.57 & MTAR* & 8.06 & 4.69 & & & yes,asym & yes & MTAR* \\
\hline \multicolumn{19}{|c|}{ Panel D: Relationship of national bank rate to South African T-bill rat } \\
\hline South Africa & deposit & 1991.01 & 2005.05 & 173 & 610.87 & 607.94 & 609.27 & 610.94 & 602.12 & 602.12 & MTAR* & 10.80 & 8.80 & & & yes,asym & yes & MTAR* \\
\hline South Africa & deposit & 1991.01 & 1998.08 & 92 & 264.99 & 260.14 & 259.41 & 265.24 & 253.60 & 253.60 & MTAR* & 13.39 & 13.38 & & & yes,asym & yes & MTAR* \\
\hline South Africa & deposit & 1998.09 & 2005.05 & 81 & 180.54 & 172.72 & 174.00 & 180.77 & 169.68 & 169.68 & MTAR* & 14.98 & 13.82 & & & yes,asym & yes & MTAR* \\
\hline South Africa & prime lending & 1991.01 & 2005.05 & 173 & 536.40 & 535.29 & 529.65 & 535.11 & 522.21 & 522.21 & MTAR* & 12.09 & 14.42 & & & yes,asym & yes & MTAR* \\
\hline South Africa & prime lending & 1991.01 & 1997.05 & 77 & 161.83 & 161.50 & 161.33 & 161.98 & 158.54 & 158.54 & MTAR* & 3.51 & 3.26 & & & no & yes & SYM \\
\hline South Africa & prime lending & 1997.06 & 2005.05 & 96 & 251.72 & 250.50 & 246.89 & 248.96 & 246.32 & 246.32 & MTAR* & 17.86 & 5.54 & & & yes,asym & yes & MTAR* \\
\hline Lesotho & deposit & 1991.01 & 2005.05 & 173 & 793.21 & 792.38 & 792.75 & 789.13 & 787.55 & 787.55 & MTAR* & 5.37 & 5.57 & & & no & no & STD \\
\hline Lesotho & deposit & 1991.01 & 1998.05 & 89 & 311.78 & 307.59 & 303.08 & 312.09 & 307.95 & 303.08 & BTAR* & 5.80 & 9.98 & 2.21 & 11.06 & no & no & STD \\
\hline Lesotho & deposit & 1998.06 & 2005.05 & 84 & 313.32 & 312.13 & 309.83 & 313.29 & 300.55 & 300.55 & MTAR* & 19.37 & 13.53 & & & yes,asym & yes & MTAR* \\
\hline Lesotho & prime lending & 1991.01 & 2005.05 & 173 & 798.86 & 797.62 & 799.40 & 799.37 & 778.92 & 778.92 & MTAR* & 12.13 & 21.24 & & & yes,asym & yes & MTAR* \\
\hline Lesotho & prime lending & 1991.01 & 1998.11 & 95 & 411.21 & 407.23 & 406.91 & 412.88 & 407.13 & 406.91 & BTAR* & 5.09 & 7.42 & 0.15 & 2.17 & no & yes & SYM \\
\hline Lesotho & prime lending & 1998.12 & 2005.05 & 78 & 220.51 & 216.84 & 213.40 & 220.49 & 217.78 & 213.40 & BTAR* & 4.31 & 8.39 & 0.42 & 9.19 & no & no & STD \\
\hline Swaziland & deposit & 1991.01 & 2005.05 & 173 & 551.52 & 550.53 & 551.31 & 545.29 & 538.68 & 538.68 & MTAR* & 18.12 & 13.05 & & & yes,asym & yes & MTAR* \\
\hline Swaziland & deposit & 1991.01 & 1992.10 & 22 & -37.46 & -37.46 & -71.12 & -18.43 & -67.98 & -71.12 & BTAR* & 87.99 & 239.21 & 3.52 & 71.47 & yes,asym & no & BTAR* \\
\hline Swaziland & deposit & 1992.11 & 2005.05 & 151 & 489.92 & 489.40 & 489.08 & 489.50 & 485.49 & 485.49 & MTAR* & 17.54 & 4.47 & & & yes,asym & yes & MTAR* \\
\hline Swaziland & prime lending & 1991.01 & 2005.05 & 173 & 576.24 & 575.76 & 575.33 & 571.79 & 567.65 & 567.65 & MTAR* & 10.09 & 8.52 & & & yes,asym & yes & MTAR* \\
\hline Swaziland & prime lending & 1991.01 & 1995.02 & 50 & 44.37 & 42.04 & 41.47 & 23.71 & 20.54 & 20.54 & MTAR* & 18.04 & 27.28 & & & yes,asym & no & MTAR* \\
\hline Swaziland & prime lending & 1995.03 & 2005.05 & 123 & 407.49 & 406.16 & 394.84 & 407.64 & 401.58 & 394.84 & BTAR* & 15.83 & 14.95 & 0.50 & 14.92 & yes,asym & yes & BTAR* \\
\hline Namibia & deposit & 1991.01 & 2005.05 & 173 & 556.22 & 553.88 & 555.23 & 554.12 & 535.70 & 535.70 & MTAR* & 16.62 & 21.08 & & & yes,asym & yes & MTAR* \\
\hline Namibia & deposit & 1995.09 & 1999.11 & 107 & 272.16 & 269.90 & 269.90 & 267.48 & 259.24 & 259.24 & MTAR* & 13.49 & 13.20 & & & yes,asym & yes & MTAR* \\
\hline Namibia & deposit & 1999.12 & 2005.05 & 66 & 129.28 & 126.44 & 122.42 & 127.97 & 119.68 & 119.68 & MTAR* & 8.70 & 10.28 & & & yes,asym & no & MTAR* \\
\hline Namibia & prime lending & 1991.01 & 2005.05 & 173 & 797.20 & 796.67 & 793.42 & 796.30 & 790.78 & 790.78 & MTAR* & 8.02 & 6.34 & & & yes,asym & yes & MTAR* \\
\hline Namibia & prime lending & 1991.01 & 1994.09 & 45 & 122.45 & 119.66 & 120.46 & 123.00 & 121.83 & 119.66 & TAR* & 5.05 & 3.10 & & & no & yes & SYM \\
\hline Namibia & prime lending & 1994.10 & 2005.05 & 128 & 574.12 & 571.62 & 570.88 & 573.93 & 569.67 & 569.67 & MTAR* & 8.15 & 4.62 & & & yes,asym & yes & MTAR* \\
\hline
\end{tabular}




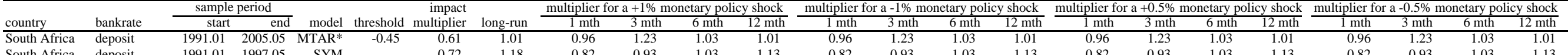
$\begin{array}{lll}-0.45 & 0.61 & 1.01 \\ -0.72 & 0.72 & 1.18\end{array}$ $\begin{array}{lll}1991.01 & 1997.05 & \text { SYM }\end{array}$

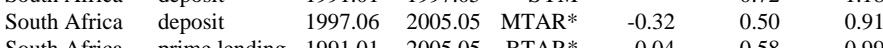
$\begin{array}{lllll}\text { South Africa } & \text { prime lending } 1991.01 & 2005.05 & \text { BTAR* } \\ \text { Lesotho } & \text { deposit } & 1991.01 & 2005.05 & \text { STD }\end{array}$

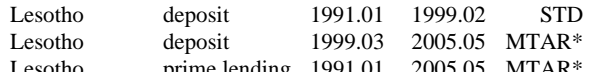

Lesotho prime lending $1991.01 \quad 2005.05$ MTAR*

Lesotho

Lesotho

Swaziliand

Swaziland

Swaziland

Swaziland

Namibia prime lending $2003.06 \quad 2005.05$ BTAR* $\begin{array}{lll}\text { prime lending } 2003.06 & 2005.05 & \text { SYM } \\ \end{array}$ $\begin{array}{llll}\text { deposit } & 1991.01 & 2005.05 & \text { MTAR* } \\ \text { deposit } & 1991.01 & 1994.09 & \text { MTARO }\end{array}$ deposit $\quad 1991.01 \quad 1994.09$ MTAR0 prime lending $\begin{array}{lll}1991.01 & 2005.05 & \text { MTAR* }^{*}\end{array}$ prime lending 1991.01 2003.08 MTAR* $^{*}$ $\begin{array}{lllll}\text { prime lending } 2003.09 & 2005.05 & \text { BTAR* }^{*} & -0.02 \\ & & 0.00\end{array}$

$\begin{array}{llll}\text { deposit } & 1991.01 & 2005.05 & \text { BTAR }^{*} \\ \text { deposit } & 1991.01 & 1095 & \\ & & \end{array}$ $\begin{array}{llll} & 1995.11 & 2005.05 & \text { STD }\end{array}$

$\begin{array}{llllll}0.50 & 0.91 & 0.91 & 1.11 & 0.84 & 0.90 \\ 0.58 & 0.99 & 1.01 & 1.07 & 1.04 & 1.04\end{array}$ $\begin{array}{ll}0.08 & 0.06 \\ 0.07 & 0.07\end{array}$

$\begin{array}{lll}0.07 & 0.07 & 0.07 \\ 0.06 & 0.26 & 0.02\end{array}$
$\begin{array}{llll}0.06 & 0.06 & 0.06 & 0.06 \\ 0.07 & 0.07 & 0.07 & 0.07\end{array}$ $\begin{array}{ll}0.07 & 0.07 \\ 0.08 & 0.18\end{array}$

$\begin{array}{llllll}0.61 & 0.89 & 0.46 & 0.57 & 0.67 & 0.73\end{array}$

prime lending 1991.01

amibia prime

$\begin{array}{llllll}0.76 & 0.78 & 0.72 & 0.34 & 0.76 \\ 0.68 & 0.76 & 0.84 & 0.37\end{array}$

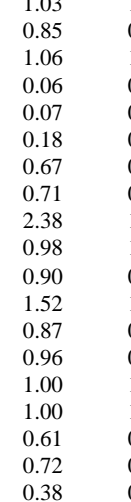

1.13
0.91
1.06
0.06
0.07
0.25
0.73
0.70
1.74
1.04
0.89
1.58
0.87
0.96
1.00
1.00
0.49
0.72
0.38

0.82
0.91
1.01
0.06
0.07
0.02
0.46
0.47
-0.15
0.94
0.88
1.38
0.88
0.97
1.00
1.00
0.46
0.57
0.34
0.71

$\begin{array}{ll}0.82 & 0.93 \\ 0.91 & 1.23 \\ .01 & 1.03 \\ 0.06 & 0.06 \\ 0.07 & 0.07 \\ 0.02 & 0.08 \\ 0.46 & 0.57 \\ 0.47 & 0.61 \\ -0.15 & 0.03 \\ 0.94 & 1.34 \\ 0.88 & 0.89 \\ 1.38 & 1.30 \\ 0.88 & 0.87 \\ 0.97 & 0.94 \\ 1.00 & 1.00 \\ 1.00 & 1.00 \\ 0.46 & 0.81 \\ 0.57 & 0.76 \\ 0.34 & 0.37 \\ 0.71 & \end{array}$

$\begin{array}{lll}0.93 & 1.03 & 1.13 \\ 1.23 & 0.85 & 0.91 \\ 1.03 & 0.97 & 0.98 \\ 0.06 & 0.06 & 0.06 \\ 0.07 & 0.07 & 0.07 \\ 0.08 & 0.18 & 0.25 \\ 0.57 & 0.67 & 0.73 \\ 0.61 & 0.71 & 0.70 \\ 0.03 & 0.42 & 0.92 \\ 1.34 & 0.98 & 1.04 \\ 0.89 & 0.90 & 0.89 \\ 1.30 & 1.13 & 0.45 \\ 0.87 & 0.87 & 0.87 \\ 0.94 & 0.95 & 0.95 \\ 1.00 & 1.00 & 1.00 \\ 1.00 & 1.00 & 1.00 \\ 0.81 & 0.71 & 0.83 \\ 0.76 & 0.72 & 0.72 \\ 0.37 & 0.38 & 0.38 \\ 0 & 0.76 & 0.84\end{array}$

0.91
0.98
0.06
0.07
0.25
0.73
0.70
0.92
1.04
0.89
0.45
0.87
0.95
1.00
1.00
0.83
0.72
0.38
0.84

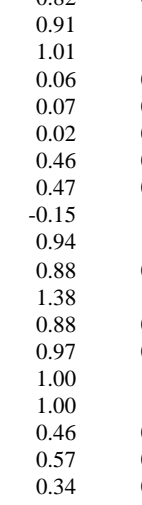

$\begin{array}{lrr}1.23 & 0.85 & 0.91 \\ 1.03 & 0.97 & 0.98 \\ 0.06 & 0.06 & 0.06 \\ 0.07 & 0.07 & 0.07 \\ 0.08 & 0.18 & 0.25 \\ 0.57 & 0.67 & 0.73 \\ 0.61 & 0.71 & 0.7 \\ 1.31 & 2.01 & 1.54 \\ 1.34 & 0.98 & 1.04 \\ 0.89 & 0.9 & 0.89 \\ 1.53 & 1.52 & 1.58 \\ 0.87 & 0.87 & 0.87 \\ 0.94 & 0.95 & 0.95 \\ 1.00 & 1.00 & 1.00 \\ 1.00 & 1.00 & 1.00 \\ 0.93 & 0.58 & 0.34 \\ 0.76 & 0.72 & 0.72 \\ 0.37 & 0.38 & 0.38 \\ 0.68 & 0.76 & 0.84\end{array}$

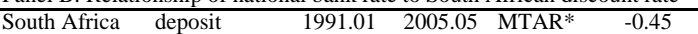

South Africa deposit

$1991.01 \quad 1997.05 \quad$ SYM

$\begin{array}{llll}0.61 & 1.01 & 0.96 & 1.23 \\ 0.72 & 1.18 & 0.82 & 0.93 \\ 0.50 & 0.91 & 0.91 & 1.11\end{array}$

$\begin{array}{ll}1.03 & 1.01 \\ 1.03 & 1.13\end{array}$

$0.68-0.76-0.84$

0.68

0.38

South Africa

Lesotho

Lesotho

Lesotho
Lesotho

Lesotho

Swaziland

Swaziland
Swaziland

Swaziland

Swaziland

Namibia

Namicia

Namibia

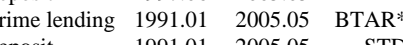

$\begin{array}{llll} & 1991.01 & 2005.05 & \text { STD } \\ \text { deposit } & 1991.01 & 1998.03 & \text { STD }\end{array}$

1998.042005 .05 MTAR*

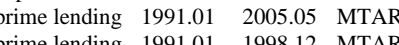

$\begin{array}{llll}\text { prime lending } & 1999.01 & 2005.05 & \text { SYM }\end{array}$

$\begin{array}{llll}\text { deposit } & 1991.01 & 2005.05 & \text { MTAR0 }\end{array}$

$\begin{array}{llrr}1991.01 & 1992.09 & \text { STD } \\ \text { deposit } & 1992.10 & 2005.05 & \text { MTAR0 }\end{array}$

$\begin{array}{llll}1991.10 & 2005.05 & \text { MTAR0 } \\ \text { prime lending } & 1991.01 & 2005.05 & \text { MTAR }^{*}\end{array}$

$\begin{array}{llll}\text { prime lending } & 1991.01 & 1995.02 & \text { MTAR* } \\ \text { prime lending } & 1995.03 & 2005.05 & \text { MTAR* }\end{array}$

$\begin{array}{llll}\text { prime lending } & 1995.03 & 2005.05 & \text { MTAR* }^{*} \\ \text { deposit } & 1991.01 & 2005.05 & \text { MTAR* }^{*}\end{array}$

$\begin{array}{llll}\text { deposit } & 1991.01 & 1999.12 & \text { SYM } \\ \text { depsit } & 20001 & 2005.05 & \text { SYD }\end{array}$

$\begin{array}{lllr}\text { deposit } & 2000.01 & 2005.05 & \text { STD } \\ \text { prime lending } & 1991.01 & 2005.05 & \text { MTAR* }\end{array}$

$\begin{array}{llll}\text { prime lending } & 1991.01 & 1994.08 & \text { MTAR0 } \\ \text { prime lending } & 1994.09 & 2005.05 & \text { TAR* }\end{array}$

$\begin{array}{lllllll}0.45 & 0.72 & 1.18 & 0.82 & 0.93 & 1.03 & 1.13 \\ 0.04 & 0.50 & 0.91 & 0.91 & 1.11 & 0.84 & 0.90 \\ & 0.58 & 0.99 & 1.01 & 1.07 & 1.04 & 1.04\end{array}$

$\begin{array}{lllll}0.58 & 0.99 & 1.01 & 1.07 & 1.04 \\ 0.38 & 0.32 & 0.31 & 0.32 & 0.32\end{array}$

$\begin{array}{ll}0.38 & 0.32 \\ 0.42 & 0.42\end{array}$

$\begin{array}{lll}0.31 & 0.32 & 0.32 \\ 0.42 & 0.42 & 0.42\end{array}$

$\begin{array}{lll}0.75 & 0.26 \\ 1.00 & 0.17 & 0\end{array}$

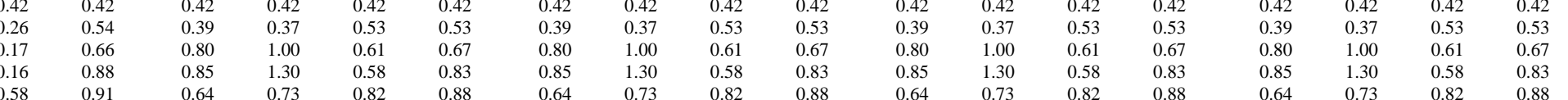

$\begin{array}{lll}1.00 & 0.17 & 0.66 \\ 1.00 & 0.16 & 0.88\end{array}$

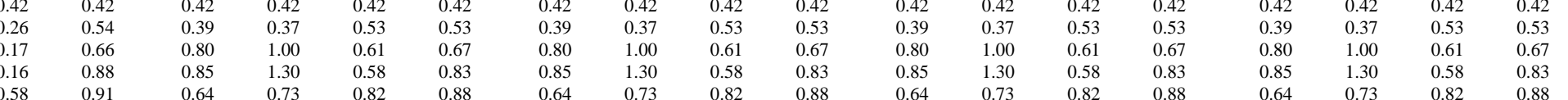

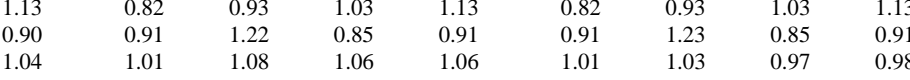

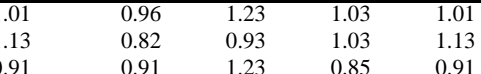

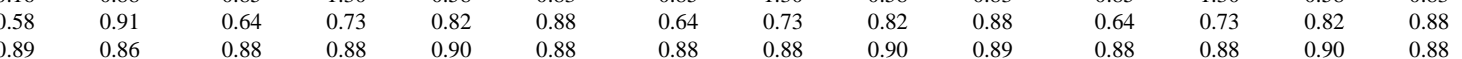

$\begin{array}{rr}0.89 & 0.86 \\ -0.08 & -0.16\end{array}$

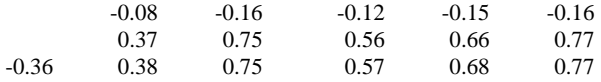

$\begin{array}{llllll}-0.36 & 0.38 & 0.75 & 0.57 & 0.68 & 0.77 \\ -0.33 & 0.14 & 0.40 & 0.42 & 0.40 & 0.40 \\ -0.28 & 0.50 & 0.84 & 0.59 & 0.67 & 0.84\end{array}$

$\begin{array}{ll}0.03 & 0.70 \\ 0.18 & 0.63\end{array}$

$\begin{array}{lll}0.37 & 0.67 & 0.84 \\ 0.35 & 0.56 & 0.62\end{array}$

$\begin{array}{rrrrr}-0.16 & -0.12 & -0.15 & -0.16 & -0.16 \\ 0.78 & 0.56 & 0.65 & 0.78 & 0.78\end{array}$

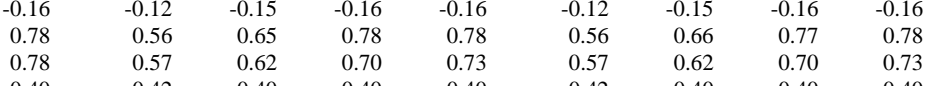

$\begin{array}{lllllllll}0.40 & 0.42 & 0.40 & 0.40 & 0.40 & 0.42 & 0.40 & 0.40 & 0.40 \\ 0.88 & 0.59 & 0.62 & 0.78 & 0.86 & 0.59 & 0.62 & 0.78 & 0.86\end{array}$

$\begin{array}{lllllllll}0.63 & 0.37 & 0.56 & 0.62 & 0.63 & 0.59 & 0.62 & 0.78 & 0.86 \\ 0.63 & 0.35 & 0.54 & 0.62 & 0.63 & 0.35 & 0.56 & 0.62 & 0.63 \\ 0.08 & 0.08 & .08 & 0.08 & 0.03 & 0.06 & 0.63\end{array}$

$\begin{array}{llllllll}0.35 & 0.54 & 0.62 & 0.63 & 0.35 & 0.54 & 0.62 & 0.63 \\ 0.08 & 0.08 & 0.08 & 0.08 & 0.08 & 0.08 & 0.08 & 0.08\end{array}$

$\begin{array}{llllllll}0.66 & 0.65 & 0.73 & 0.82 & 0.66 & 0.65 & 0.73 & 0.82 \\ 1.31 & 1.00 & 1.28 & 1.15 & 1.31 & 0.82 & 1.15 & 1.14 \\ 0.64 & 0.77 & 0.76 & 0.82 & 0.64 & 0.74 & 0.74 & 0.80\end{array}$

Panel C: Relationship of national bank rate to national T-bill rate

\begin{tabular}{lllll}
\hline South Africa & deposit & 1991.01 & 2005.05 & MTAR $^{*}$ \\
South Africa & deposit & 1991.01 & 1998.08 & MTAR* $^{*}$ \\
& & & &
\end{tabular}

South Africa

$\begin{array}{llll} & 1991.01 & 1998.08 & \text { MTAR* }^{*} \\ \text { deposit } & 1998.09 & 2005.05 & \text { MTAR* }^{*}\end{array}$

$\begin{array}{lllll}\text { South Africa } & \text { prime lending } & 1991.01 & 2005.05 & \text { MTAR* } \\ & \text { prime lending } & 1991.01 & 1997.05 & \text { SYM }\end{array}$

South Africa $\quad$ prime lending 1997.06 2005.05 MTAR*

Lesotho deposit 1991.01 2005.05 STD

Lesotho

Lesotho

Lesotho
Lesotho

Lesotho

Swaziland

Swaziland

Swaziland

Swaziland

$\begin{array}{llll}\text { deposit } & 1991.01 & 1998.06 & \text { STD } \\ \text { deposit } & 1998.07 & 2005.05 & \text { MTAR* }\end{array}$

$\begin{array}{llll}\text { prime lending } & 1991.01 & 2005.05 & \text { MTAR* } \\ & \text { MTAR } & \\ \text { pint } & \text { 2003.05 } & \text { MTAR }\end{array}$ prime lending $1991.01 \quad 2003.05$ MTAR* $^{*}$

\begin{tabular}{lllll} 
prime lending & 2003.06 & 2005.05 & MTAR* $^{*}$ & -0.36 \\
deposit & 1991.01 & 2005.05 & MTAR* $^{*}$ & -1.45 \\
\hline
\end{tabular}

$\begin{array}{llllll}\text { deposit } & & 1991.01 & 2003.04 & \text { BTAR* }^{*} & 0.12 \\ & 2003.05 & 2005.05 & \text { MTAR* }^{*} & 0.19\end{array}$

$\begin{array}{llll}\text { deposit } 2003.05 & 2005.05 & \text { SYM }\end{array}$

$\begin{array}{llll}\text { prime lending } & 1991.01 & 2003.05 & \text { SYM }\end{array}$

$\begin{array}{rr}0.63 & 0.93 \\ -0.54 & 0.97 \\ -0.31 & 0.71 \\ 0.71 & 0.8 \\ & 0.50 \\ 0.43 & 1.1 \\ & 0.03 \\ & -0.03 \\ 0.33 & 0.13 \\ 1.40 & 0.58 \\ 1.40 & 0.56 \\ -0.36 & 0.25 \\ -1.45 & 0.15 \\ 0.12 & 0.15 \\ 0.19 & 0.55 \\ & 0.56 \\ & \\ & \end{array}$

$\begin{array}{ll}0.93 & 1.09 \\ 0.97 & 1.03 \\ 0.71 & 1.01\end{array}$

$\begin{array}{llll}1.31 & 0.82 & 1.15 & 1.14 \\ 0.64 & 0.74 & 0.74 & 0.80\end{array}$

$\begin{array}{rrr} & & \\ 0.83 & 0.76 & 1.1 \\ 0.83 & 0.78 & 1.07 \\ 0.74 & 0.98 & 1.00 \\ 0.84 & 0.86 & 1.00 \\ 0.59 & 0.71 & 0.78 \\ 0.87 & 0.81 & 1.23 \\ 0.02 & 0.02 & 0.02 \\ -0.03 & -0.03 & -0.03 \\ 0.14 & 0.45 & 0.61 \\ 0.55 & 0.63 & 0.60 \\ 0.48 & 0.54 & 0.52 \\ 0.47 & 0.87 & 1 . \\ 0.34 & 0.48 & 0.42 \\ 0.31 & 0.35 & 0.41 \\ 0.94 & 0.98 & 0.99 \\ 0.95 & 0.87 & 0.88 \\ 0.13 & 0.13 & 0.13 \\ 0.20 & 0.27 & 0.35 \\ & & \end{array}$

$\begin{array}{rr}1.12 & 1.07 \\ 1.07 & 1.03 \\ 1.00 & 0.99 \\ 1.00 & 1.01 \\ 0.78 & 0.82 \\ 1.23 & 1.19 \\ 0.02 & 0.02 \\ -0.03 & -0.03 \\ 0.61 & 0.63 \\ 0.60 & 0.65 \\ 0.52 & 0.56 \\ 1.10 & 0.88 \\ 0.42 & 0.46 \\ 0.41 & 0.44 \\ 0.99 & 0.95 \\ 0.88 & 0.88 \\ 0.13 & 0.13 \\ 0.35 & 0.48\end{array}$

$\begin{array}{rrr} & & \\ 0.76 & 1.12 & 1.07 \\ 0.78 & 1.07 & 1.03 \\ 0.98 & 1.00 & 0.99 \\ 0.86 & 1.00 & 1.01 \\ 0.71 & 0.78 & 0.82 \\ 0.81 & 1.23 & 1.19 \\ 0.02 & 0.02 & 0.02 \\ -0.03 & -0.03 & -0.03 \\ 0.31 & 0.49 & 0.56 \\ 0.63 & 0.60 & 0.65 \\ 0.54 & 0.52 & 0.5 \\ 0.87 & 1.10 & 0.88 \\ 0.48 & 0.42 & 0.46 \\ 0.35 & 0.41 & 0.44 \\ 0.54 & 0.60 & 0.63 \\ 0.87 & 0.88 & 0.8 \\ 0.13 & 0.13 & 0.13 \\ 0.27 & 0.35 & 0.48 \\ & & \end{array}$

$\begin{array}{rrrrr} & & & & \\ 1.07 & 0.83 & 0.76 & 1.12 & 1.07 \\ 1.03 & 0.83 & 0.78 & 1.07 & 1.03 \\ 0.99 & 0.74 & 0.98 & 1.00 & 0.99 \\ 1.01 & 0.84 & 0.86 & 1.00 & 1.01 \\ 0.82 & 0.59 & 0.71 & 0.78 & 0.82 \\ 1.19 & 0.87 & 0.81 & 1.23 & 1.19 \\ 0.02 & 0.02 & 0.02 & 0.02 & 0.02 \\ -0.03 & -0.03 & -0.03 & -0.03 & -0.03 \\ 0.56 & 0.14 & 0.31 & 0.49 & 0.56 \\ 0.65 & 0.55 & 0.63 & 0.60 & 0.65 \\ 0.56 & 0.48 & 0.54 & 0.52 & 0.56 \\ 0.88 & 0.47 & 0.87 & 1.10 & 0.88 \\ 0.46 & 0.34 & 0.48 & 0.42 & 0.46 \\ 0.44 & 0.31 & 0.35 & 0.41 & 0.44 \\ 0.63 & 0.94 & 0.92 & 0.72 & 0.75 \\ 0.88 & 0.95 & 0.87 & 0.88 & 0.88 \\ 0.13 & 0.13 & 0.13 & 0.13 & 0.13 \\ 0.48 & 0.20 & 0.27 & 0.35 & 0.48 \\ & & & & \end{array}$


multiplier for a $+1 \%$ monetary policy shock $\frac{\text { multiplier for a }-1 \% \text { monetary policy shock }}{1} \frac{\text { multiplier for a }+0.5 \% \text { monetary policy shock }}{3} \frac{\text { multiplier for a }-0.5 \% \text { monetary policy shock }}{3}$

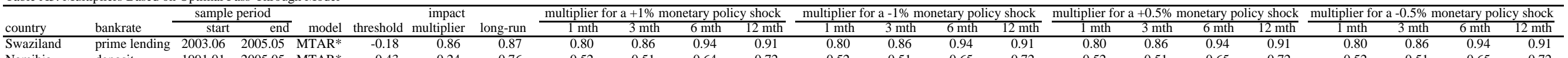
Swaziland prime lending 2003.06 $\begin{array}{llllll}1991.01 & 1999.09 & \text { MTAR* } & -0.04 & 0.29 & 0.63\end{array}$

Namibia

Nambia deposit $\quad 1999.10 \quad 2005.05$ MTAR* $^{*}$ prme lending $1991.01 \quad 2005.05$ BTAR* $^{*}$ prime lending $1991.01 \quad 1954.09$ SYM

$\begin{array}{llllllll}0.52 & 0.51 & 0.64 & 0.72 & 0.52 & 0.51 & 0.65 & 0.72\end{array}$

$\begin{array}{llll}0.80 & 0.86 & 0.94 & 0.91 \\ 0.52 & 0.51 & 0.65 & 0.72 \\ 0.5 & 0.42 & 0.58 & 0.62\end{array}$

$\begin{array}{llll}0.80 & 0.86 & 0.94 & 0.91 \\ 0.52 & 0.51 & 0.65 & 0.72 \\ 0.51 & 0.42 & 0.59 & 0.62\end{array}$

$\begin{array}{llll} & \text { prime lending 1994.10 2005.05 MTAR* }\end{array}$

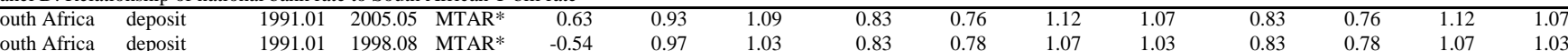

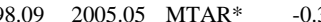

1991.012005 .05 MTAR*

South Africa prme lending 1991.01 1997.05 SYM

\begin{tabular}{llrrr} 
Lesotho & deposit & 1991.01 & 2005.05 & MTAR \\
\hline
\end{tabular}

Lesotho

Lesotho

Lesotho

Lesotho

Swaziland

Swaziland

Swaziland

Swaziland

Namibia

Namibia

Namibia

Namibia

$\begin{array}{llll}1991.01 & 1998.05 & \text { STD }\end{array}$

$\begin{array}{llll}1998.06 & 2005.05 & \text { MTAR }^{*} \\ & \text { deposit } & \end{array}$

rime lending $1991.01 \quad 1998.11 \quad$ SYM

$\begin{array}{lll}\text { deposit } & 1991.01 & 2005.05 \\ \text { MTAR* }\end{array}$

deposit

$\begin{array}{lll}1991.01 & 2005.05 & \text { MTAR* } \\ 1991.01 & 1992.10 & \text { BTAR* }\end{array}$

$\begin{array}{llll}\text { deposit } & 1992.11 & 2005.05 & \text { MTAR* }^{*} \\ \text { prime lending } & 1991.01 & 2005.05 & \text { MTAR* }^{*}\end{array}$

$\begin{array}{llll}\text { prime lending } 1991.01 & 1995.02 & \text { MTAR* } & 1.3 \\ & -0.01\end{array}$

prime lending 1995.03 2005.05 BTAR*

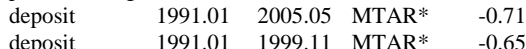

deposit $1991.01 \quad 1999.11$ MTAR

$\begin{array}{llll}0.83 & 0.78 & 1.07 & 1.03\end{array}$

0.67
0.09

$\begin{array}{lll}0.72 & 0.90 & 1.02 \\ 0.44 & 0.84 & 0.89\end{array}$

$0.48 \quad 0.72$

$\begin{array}{ll}0.98 & 1.00 \\ 0.86 & 1.00 \\ 0.71 & 0.78\end{array}$

1.03
0.99

$\begin{array}{ll}0.83 & 0.78 \\ 0.74 & 0.98\end{array}$

$\begin{array}{ll}1.07 & 1.03 \\ 1.00 & 0.99 \\ 0.00 & 1.01\end{array}$

$\begin{array}{lll}0.86 & 1.00 & 1.01 \\ 0.71 & 0.78 & 0.82\end{array}$

$\begin{array}{ll}0.84 & 0.86\end{array}$

$\begin{array}{ll}0.50 & 0.82 \\ 1.11 & 1.14\end{array}$

$\begin{array}{ll}1.00 & 1.01 \\ 0.78 & 0.82\end{array}$

$\begin{array}{llll}0.83 & 0.76 & 1.12 & 1.07 \\ 0.78 & 1.07 & 1.03\end{array}$

1.07
1.03
0.99

$\begin{array}{llll}0.83 & 0.76 & 1.12 & 1.07 \\ 0.83 & 0.78 & 1.07 & 1.03 \\ 0.74 & 0.98 & 1.00 & 0.99\end{array}$

$\begin{array}{lll}0.64 & 0.31 & 0.31\end{array}$

$\begin{array}{lll}0.82 & 0.59 & 0.86 \\ 1.19 & 0.87 & 0.81\end{array}$

$\begin{array}{llll}0.83 & 0.78 & 1.07 & 1.09 \\ 0.74 & 0.98 & 1.00 & 0.99\end{array}$

per 200505 MTAR*

prime lending $1991.01 \quad 1994.09 \quad$ SYM

$\begin{array}{lll}0.21 & 0.45 & 0.56 \\ 0.73 & 0.64 & 0.82\end{array}$

$\begin{array}{lllll}1.19 & 0.87 & 0.81 & 1.23 & 1.19 \\ 0.31 & 0.30 & 0.31 & 0.31 & 0.31\end{array}$

$\begin{array}{llll}0.84 & 0.86 & 1.00 & 1.01 \\ 0.59 & 0.71 & 0.78 & 0.82\end{array}$

$\begin{array}{llll}0.74 & 0.98 & 1.00 & 0.99 \\ 0.84 & 0.86 & 1.00 & 1.01\end{array}$

$\begin{array}{ll}0.56 & 0.61 \\ 0.80 & 0.69\end{array}$

$\begin{array}{ll}0.304 & 0.31 \\ 0.65\end{array}$

$\begin{array}{ll}0.21 & 0.45 \\ 0.73 & 0.64\end{array}$

$\begin{array}{lllll}1.31 & 0.87 & 0.81 & 1.23 & 1.19 \\ 0.31 & 0.30 & 0.31 & 0.31 & 0.31\end{array}$

\begin{tabular}{ll}
0.55 & 0.76 \\
0.70 & 0.49 \\
\hline
\end{tabular}




\section{Panel B: Prime lending rates}

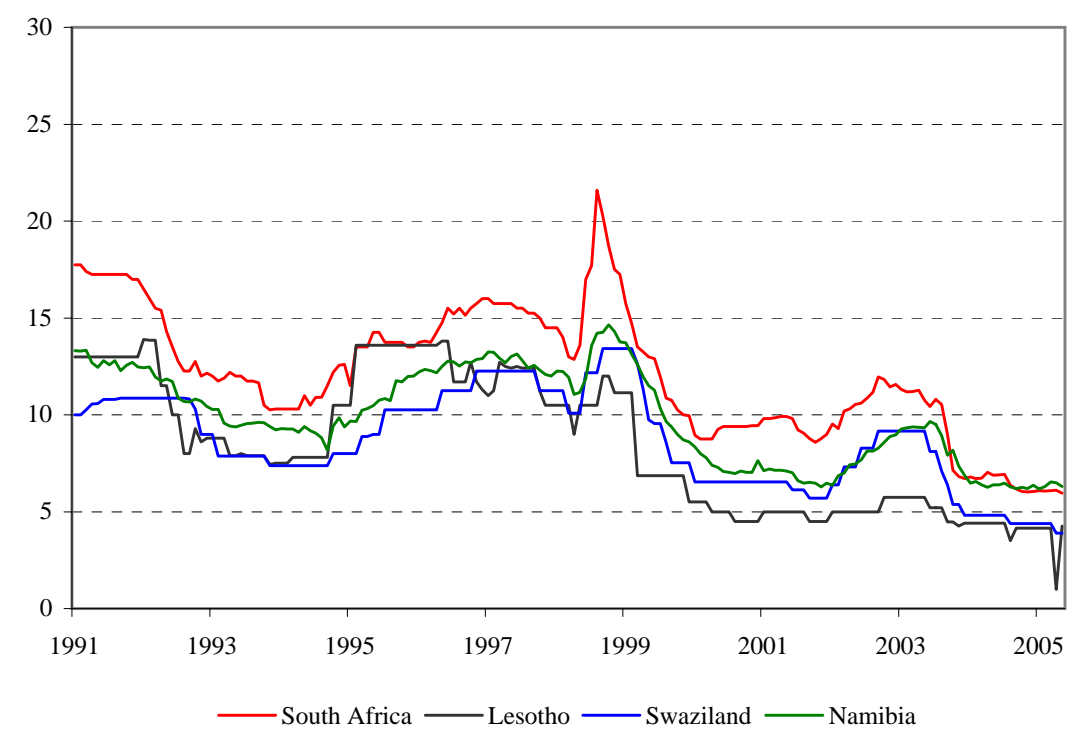

Panel C: Discount rates

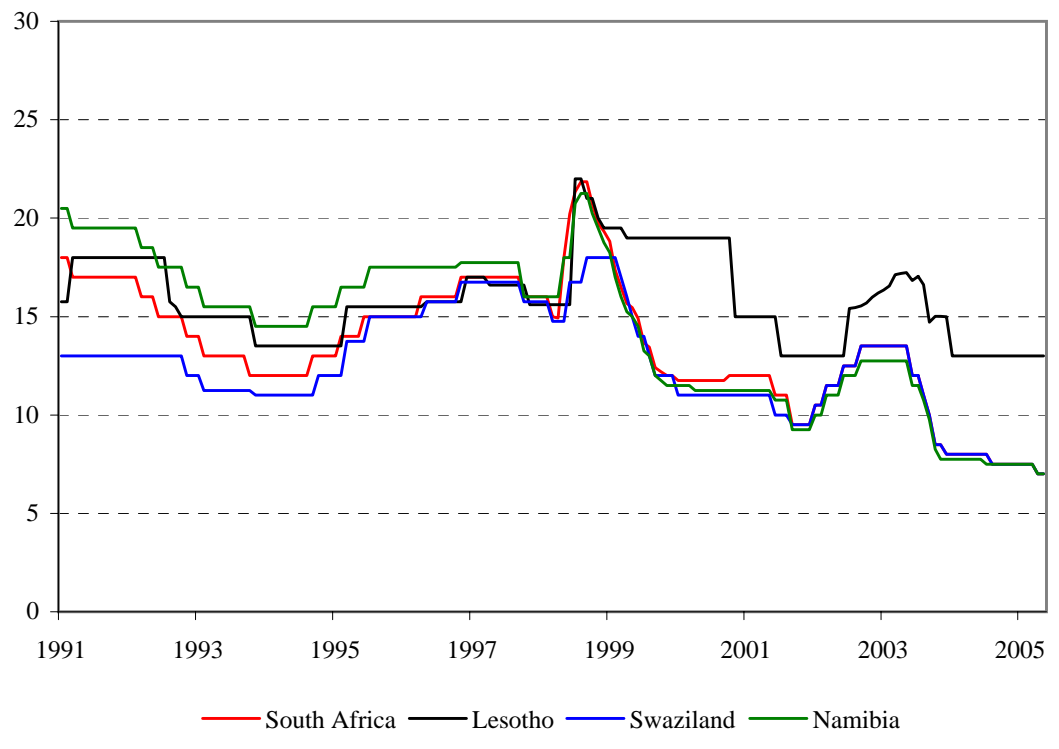

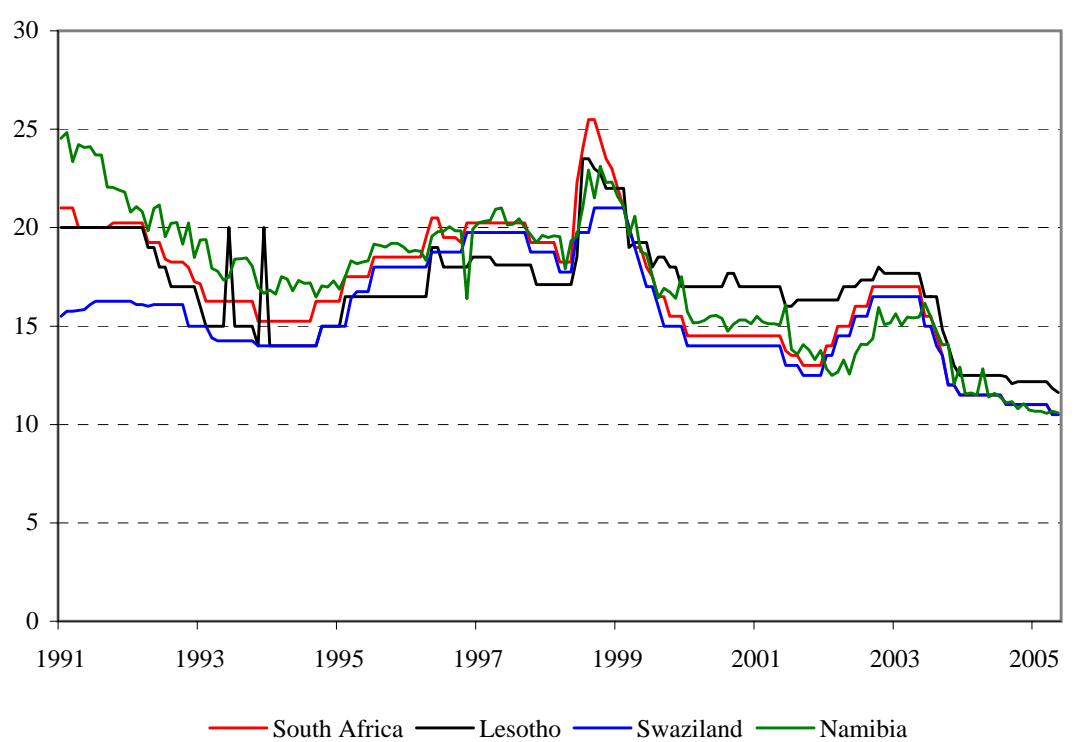

Panel D: Treasury bill rates

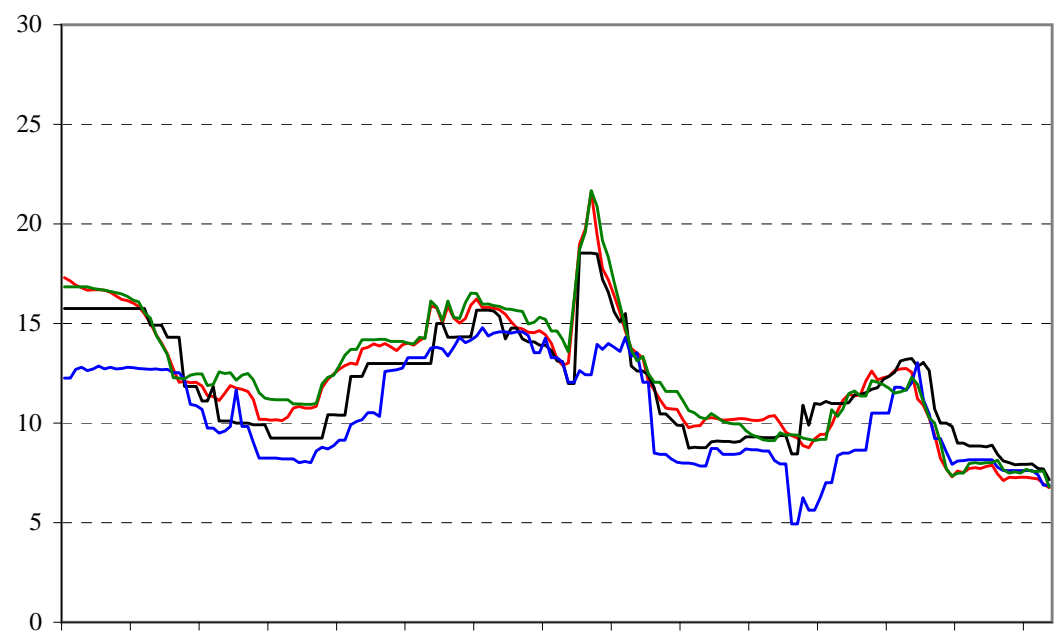

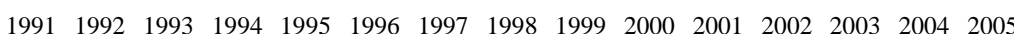


Figure 2: Rolling Chow tests regarding structural breaks in the long-run relationshi

South Africa

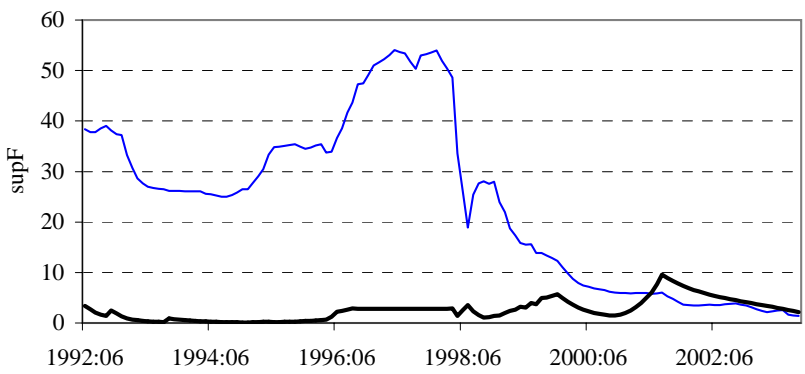

Swaziland

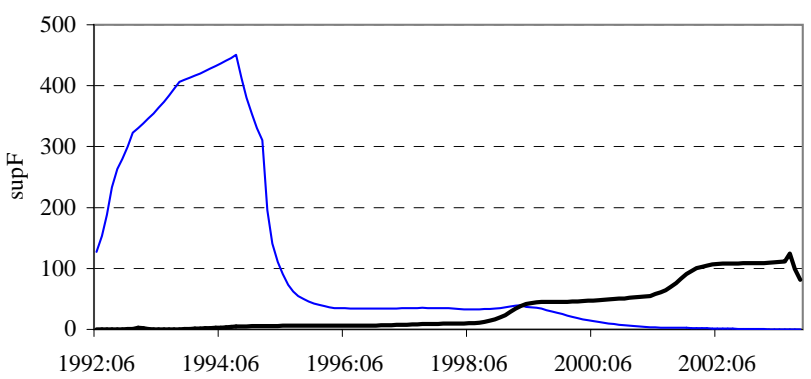

Lesotho

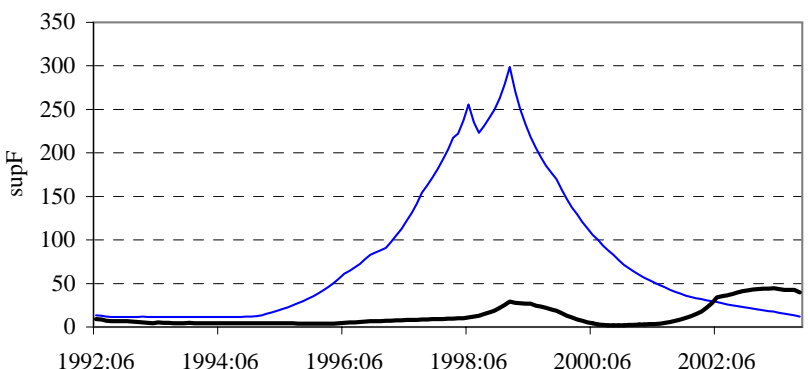

Namibia

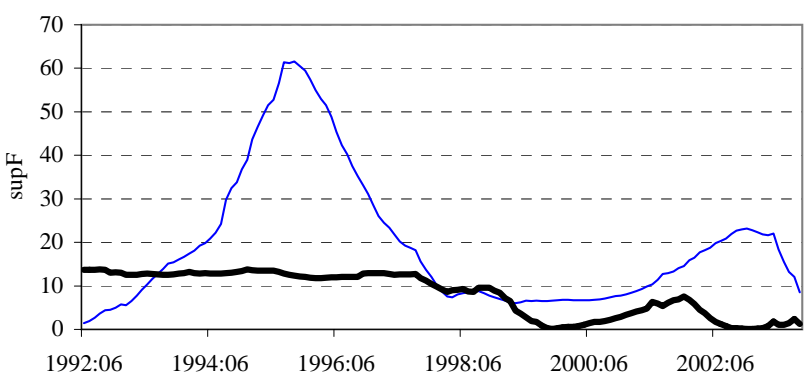

Panel B: Relationship between national bank rate and South African discount rat

South Africa

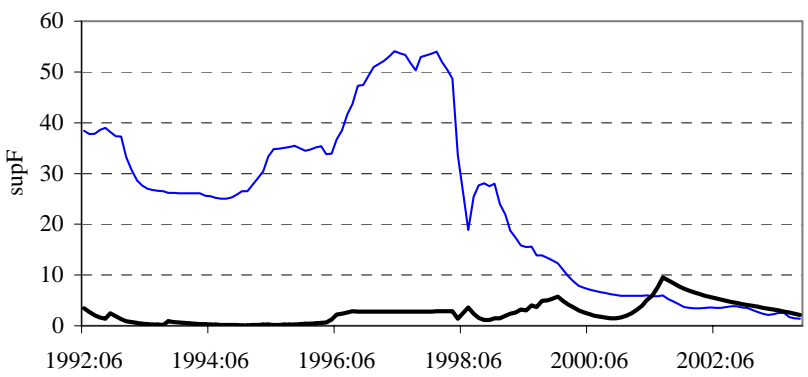

Swaziland

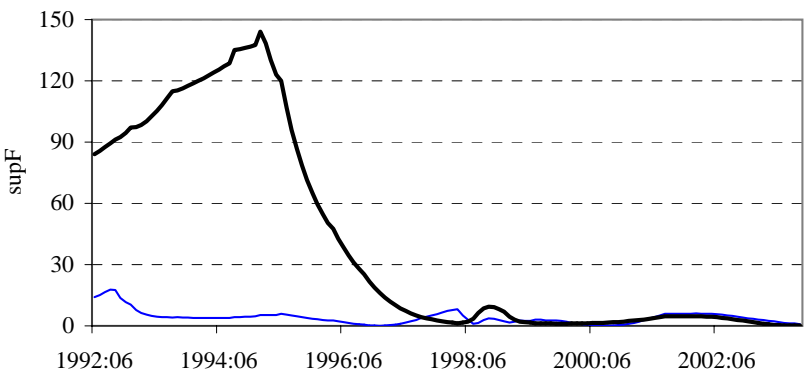

Lesotho

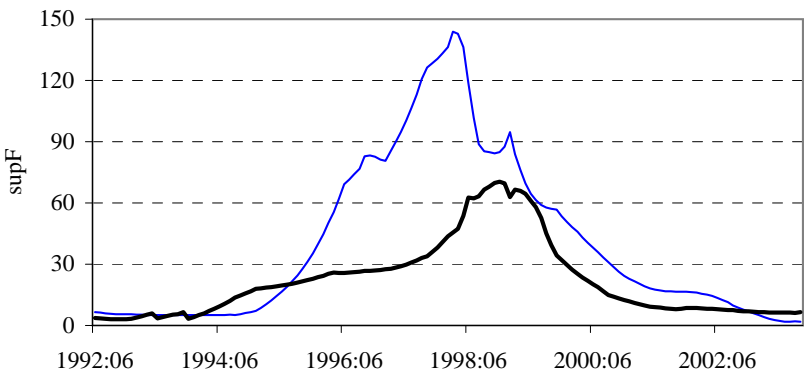

Namibia

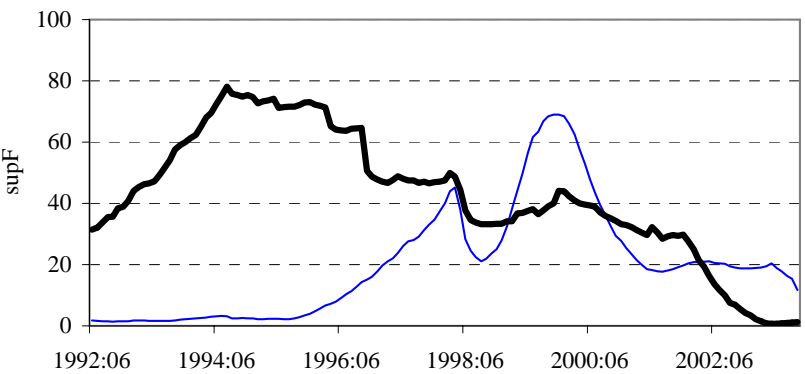


South Africa

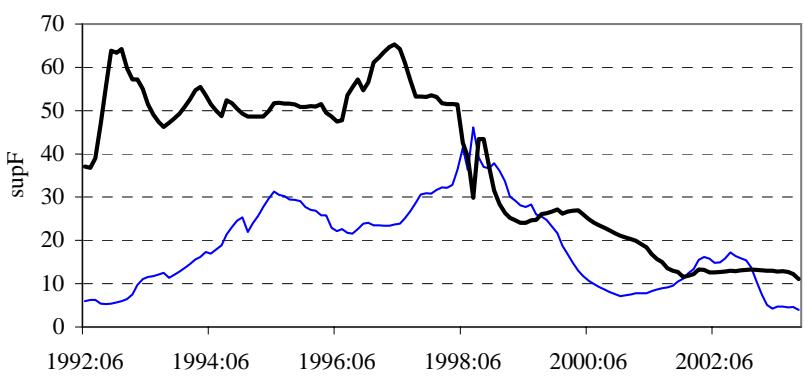

Swaziland

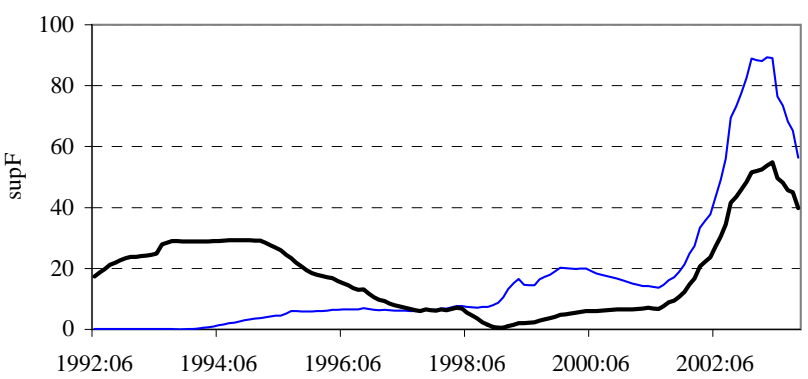

Lesotho

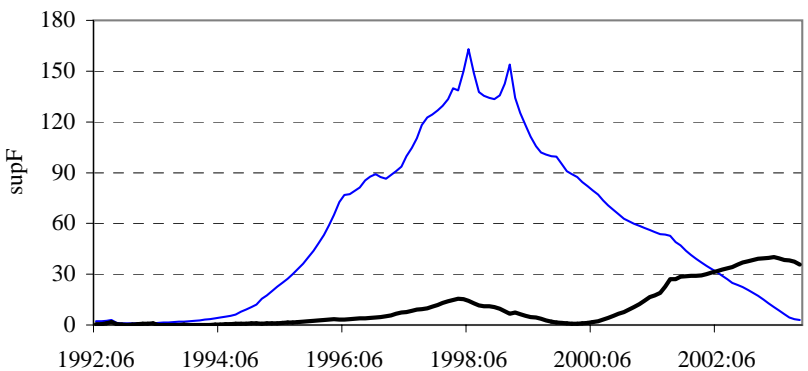

Namibia

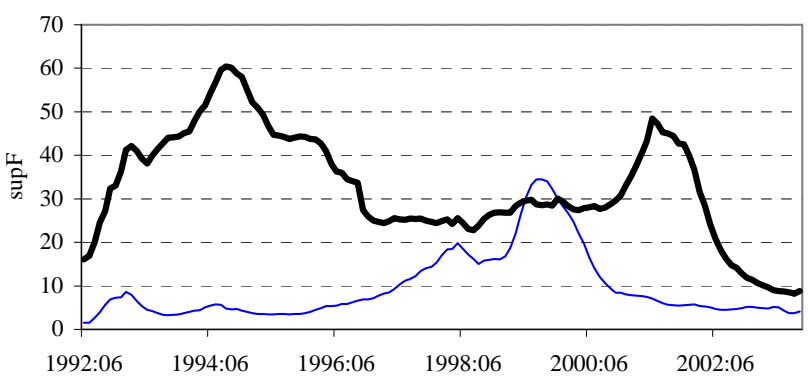

Panel D: Relationship between national bank rate and South African T-bill rat

South Africa

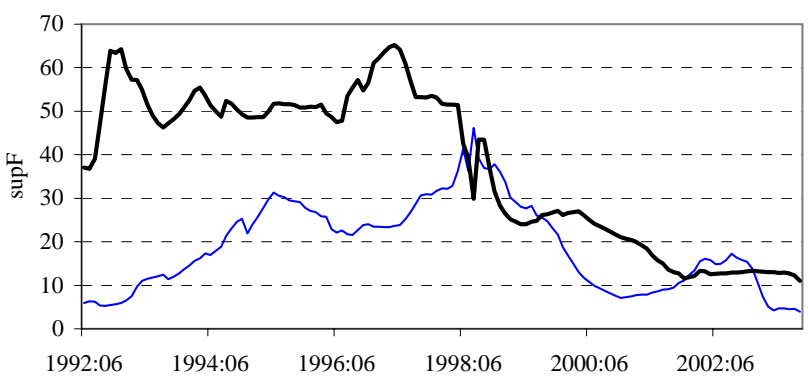

Swaziland

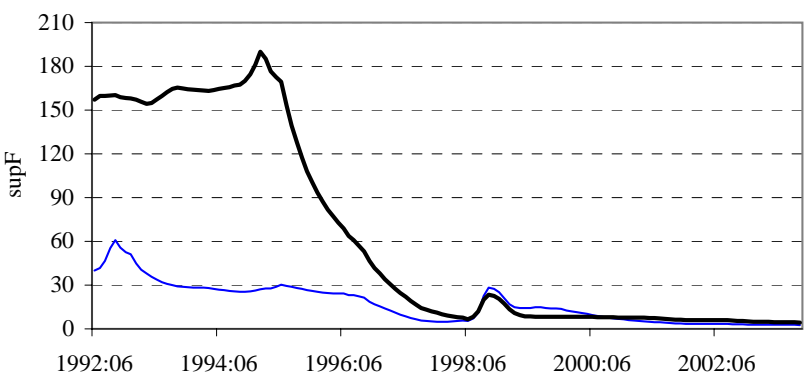

Lesotho

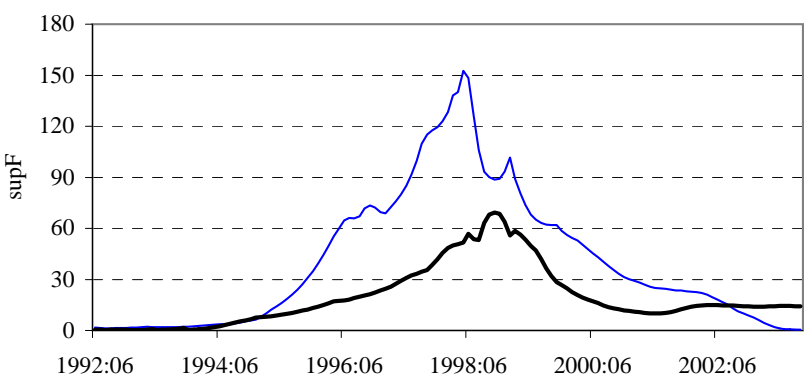

Namibia

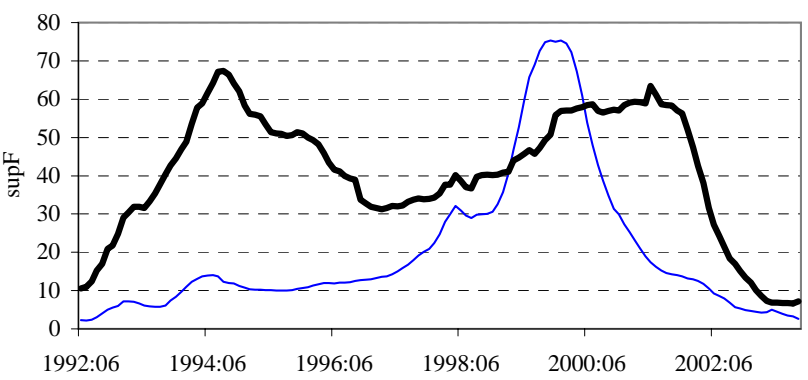

